\title{
Article \\ Nano-Porous Silica-Aerogel-Incorporated Composite Materials for Thermal-Energy-Efficient Pitched Roof in the Tropical Region
}

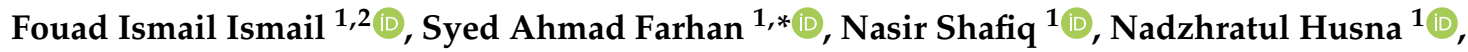 \\ Muhammad Taufiq Sharif ${ }^{3}$, Syed Uthman Affan ${ }^{4}$ and Arul Kamal Veerasenan ${ }^{4}$ \\ 1 Institute of Self-Sustainable Building for Smart Living, Universiti Teknologi PETRONAS, \\ Seri Iskandar 32610, Malaysia; fouad_20001008@utp.edu.my (F.I.I.); nasirshafiq@utp.edu.my (N.S.); \\ nadzrahusnaz@gmail.com (N.H.) \\ 2 Department of Civil Engineering, Faculty of Engineering, Al-Azhar University, Cairo 11884, Egypt \\ 3 Angkasa Consulting Services Sdn. Bhd., Taipan Business Center, Subang Jaya 47620, Malaysia; \\ taufiqsharif66@gmail.com \\ 4 Syed Uthman Expert Systems, HICOM-Glenmarie Industrial Park, Shah Alam 40150, Malaysia; \\ info.mysues@gmail.com (S.U.A.); a_kamal87@yahoo.com (A.K.V.) \\ * Correspondence: syfarisk@gmail.com
}

check for

updates

Citation: Ismail, F.I.; Farhan, S.A.; Shafiq, N.; Husna, N.; Sharif, M.T.;

Affan, S.U.; Veerasenan, A.K.

Nano-Porous Silica-Aerogel-

Incorporated Composite Materials for Thermal-Energy-Efficient Pitched Roof in the Tropical Region. Appl. Sci. 2021, 11, 6081. https://doi.org/ 10.3390/app11136081

Academic Editor: Jürgen Reichardt

Received: 31 May 2021

Accepted: 25 June 2021

Published: 30 June 2021

Publisher's Note: MDPI stays neutral with regard to jurisdictional claims in published maps and institutional affiliations.

Copyright: (c) 2021 by the authors. Licensee MDPI, Basel, Switzerland. This article is an open access article distributed under the terms and conditions of the Creative Commons Attribution (CC BY) license (https:/ / creativecommons.org/licenses/by/ $4.0 /)$.

\begin{abstract}
Silica aerogel possesses an ultra-low thermal conductivity by virtue of its nano-structure. Owing to the fragility of monolithic aerogel, the development and production of aerogel-based insulation materials involve the incorporation of granular aerogel with other materials to form composite materials. In the present study, the application of silica-aerogel-incorporated composite cement paste as render on the roof-top surface is coupled with the installation of a novel silica-aerogelincorporated composite insulation board below the roof tiles. Control and silica-aerogel-incorporated samples of the composite cement paste and insulation were prepared. Thermal conductivity and strength tests were performed on the samples. A simulation study was performed on a Building Information Model subjected to a tropical climate to project the resultant impact of the cement render coupled with the insulation board on the thermal-energy-efficiency of the roof. For optimization of thermal and strength performances, silica aerogel contents of $4 \mathrm{wt} . \%$ and $3 \mathrm{wt} . \%$ were selected for the cement render and insulation board, respectively. The projected annual cooling load and energy savings revealed that the application of a $20-\mathrm{mm}$ cement render, coupled with the installation of a $100-\mathrm{mm}$ thick insulation board, is recommended as the optimum roof configuration.
\end{abstract}

Keywords: aerogel; composite material; cooling load; pitched roof; roof insulation; roof material; roof tiles

\section{Introduction}

Aerogel was developed by Samuel Stephens Kistler in 1931 [1] and is, presently, known to man, the lightest solid in the world [2]. It is produced by replacing the liquid component of a gel with a gas to create a nano-porous solid, which, from an initial monolithic form, can then be converted to a granular form [3]. It possesses a remarkably low thermal conductivity [4] that is lower than those of other commercial insulation materials [5-7], as well as air [8-11]. It efficiently prevents solid and gaseous conduction by virtue of its non-crystalline slender skeleton and distinctive nano-sized pore structure. Accordingly, it has been labeled as a superinsulation material [12-14]. It can be synthesized from many types of materials, such as, among others, alumina, carbon, polymer, and silica [15].

Silica aerogel possesses an ultra-low thermal conductivity of $0.005 \mathrm{~W} / \mathrm{mK}$ due to its high specific surface area of $500-1200 \mathrm{~m}^{2} / \mathrm{g}$, high porosity of $80-99.8 \%$, and low density of about $0.003 \mathrm{~g} / \mathrm{cm}^{3}$ by virtue of its nano-structure [16-20]. It has a fractal geometry that can be structured randomly in colloidal aggregate systems. In general, its synthesis 
is performed in three steps, which are, preparation, aging, and drying, of silica gel. The preparation of silica gel is performed by adding a catalyst to a silica source solution to induce gelation as a result of the condensation of the liquid phase. The gel is then aged in its mother solution to increase its strength and, as a consequence, minimize the amount of shrinkage during the next step, where drying is performed at a slow rate under the conditions of supercritical drying to extricate the gel from the pore liquid without disintegrating its solid matrix, which, in the case of the conventional evaporation, will occur due to capillary action $[4,20]$.

Aerogel can be manufactured in monolithic or granular forms [3]. In general, monolithic aerogel has better thermal and optical properties than granular aerogel [21,22]. However, monolithic aerogel has been found to be fragile [23] and, consequently, susceptible to cracking during manufacturing [24]. Large-scale commercialization of monolithic aerogel is not yet actualized owing to its fragility, as well as limitations in manufacturing technology [25]. Apart from that, monolithic aerogel is expensive and requires protection from moisture and tension [21,22]. Hence, in view of the impediment to the manufacturing and application of monolithic aerogel, the adoption of aerogel in commercial products is predominantly, at present, in its granular form [21,22,25].

By virtue of its ultra-low thermal conductivity, aerogel has been employed as the insulation material for the space suits of the National Aeronautics and Space Administration of USA, underwater oil pipelines and the metallurgy industry [26]. Typically, owing to the fragility of monolithic aerogel, the development and production of aerogel-based insulation materials involve the incorporation of granular aerogel with other materials to form composite materials that can be employed as insulation materials for various applications where heat transfer is a concern. Installation of an aerogel-based insulation material in the building envelope has been explored in previous research, where the material has to concurrently fulfill thermal and strength performance requirements. The prospect of employing aerogel in the building envelope was tested for the first time in Kosny et al. [26], where the thermal performance of residential steel- and wood-framed walls and commercial low-sloped roofs that were insulated with a fiber-reinforced silica aerogel composite material were evaluated using three-dimensional computer simulations and a series of hot-box tests. Later, Morelli et al. [27] projected the effect of installing an aerogel-stone wool composite material on the interior walls and window reveals of a typical old Danish multi-family building located in Copenhagen, Denmark, along with several other measures, on the energy consumption, with the aim of retrofitting the building to become a nearly-zero-energy building. Puad et al. [28] explored the potential application of a composite insulation material, which was composed of kapok fiber and silica aerogel that were incorporated with low-density polyethylene, for residential roof under the climate of Malaysia, by concurrently evaluating its thermal and tensile strength performances. Biseniece et al. [29] evaluated the thermal performance of an aerogel blanket as a composite insulation material that was to be installed on the interior walls of a historic masonry building located in Riga, Latvia, by performing long-term in-situ measurements of heat flux and temperature. Hu et al. [30] employed an aerogel-membrane roof composed of an outer membrane layer and an inner composite membrane layer that were integrated with an aerogel blanket at an airport terminal in Hunan, China, to reduce the temperature effect and, in consequence, retard material creep strain and structural deterioration. Kosny et al. [4] developed an aerogel-incorporated radiant barrier, where an aerogel blanket was laminated with a reflective aluminized plastic foil on both sides, and analyzed its thermal performance using two test huts located in Albuquerque, New Mexico, USA, where, in the roof, the first hut did not employ any insulation, while the second hut employed the aerogel-incorporated radiant barrier.

Apart from incorporating aerogel to form composite insulation materials for the building envelope, previous research also explored the prospect of filling the cavity of the glazing component of the building envelope with aerogel to improve thermal and daylighting performances. Cotana et al. [31] evaluated the thermal-energy, lighting and acoustic perfor- 
mances of an aerogel-filled glazing through field experiments on prototype buildings with an indoor environment that typifies that of Italian residential buildings, as well as analyses in the laboratory. Abdul Mujeebu et al. [32,33] conducted simulation studies to project the effect of replacing double-glazing with aerogel-filled-glazing in windows on the energy performance of a multi-story office building that was exposed to the weather conditions of Dhahran, Kingdom of Saudi Arabia, as well as economic feasibility. Moretti et al. [14] proposed aerogel-filled polycarbonate panels to improve the thermal performance and lighting control of the building envelope for non-residential buildings, especially the roof. Mohamed et al. [5] investigated the flammability and thermal degradation of a composite material that consists of unsaturated polyester resin and expanded polystyrene, with the incorporation of silica aerogel as fillers, for the fabrication of translucent windows and roof panels with enhanced insulation properties. Bidini et al. [3] evaluated the thermal, energy and daylighting performances of an aerogel-filled double-glazed window through a field experiment that employed two test boxes in Perugia, Italy, where the first box employed the standard double-glazing window with a layer of air sealed between them, and the second box employed an identical window, but filled with a layer of granular aerogel instead of air. Buratti et al. [34] adopted a similar experimental setup but employed granular aerogel that was mixed with opaque hollow silica instead. Zheng et al. [35] evaluated the thermal and daylighting performances of an atrium with an aerogel-glazed roof in an office building in Hunan, China. Abdul Mujeebu and Ashraf [36] conducted a simulation study on the energy performance and economic feasibility of an aerogel-filled double-glazed window in a multi-story office building at various locations in the Kingdom of Saudi Arabia. Zheng et al. [25] evaluated the thermal and daylighting performances of aerogel-glazed skylight in comparison to double-glazed skylight using a test cell on the roof of a building in Changsha, China.

The roof-top surface represents the generality of surfaces that are exposed to direct solar radiation in urban areas. In addition, in the tropical region, the intensity of the direct solar radiation that reaches the roof-top surface is higher than the rest of the Earth. Concomitantly, the annual rainfall is also high; therefore, buildings in the tropical region commonly employ pitched roofs as protection, not only from the solar radiation, but also from rain water. In Malaysia, which is subjected to the tropical climate, commonly, cement roof tiles are employed as part of the pitched roof owing to their low cost and high resistance to weather conditions, albeit with inauspicious thermal properties [37], which, in the case of the roof tiles, is typically not considered the main priority [38].

At present, research on the adoption of aerogel in the building envelope is predominated by the development and evaluation of aerogel-based composite insulation materials that can be installed in the roof, on the interior wall or on the window reveal, as well as aerogel-filled glazing for the window and skylight. Accordingly, research on the adoption of aerogel on or as part of the roof tile material, coupled with the adoption of aerogel-based composite insulation materials, is deficient, notwithstanding its prospect in inducing a consequential reduction in the heat transfer through the roof, in view of the fact that the roof assembly, in the tropical region, especially the roof tiles, are directly exposed to intense and prolonged solar radiation, in addition to the high amounts of rainfall, all-year round. In the present study, the application of silica-aerogel-incorporated composite cement paste as render on the roof-top surface is coupled with the installation of a novel silica-aerogelincorporated composite insulation board below the roof tiles. Findings of the present study are most applicable to pitched roof assemblies in tropical regions and, additionally, are also relevant to those in other regions with similar climate where intense solar radiation is present.

\section{Materials and Methods}

The silica aerogel sample that was employed in the present study was obtained from a local manufacturer in Malaysia. The sample was analyzed by performing a morphology study and characterization. Silica-aerogel-incorporated composite cement paste and 
composite insulation samples were then prepared with varying amounts of silica aerogel. Thermal conductivity and strength tests were performed on the samples. A simulation study was then performed on a Building Information Model (BIM) that adopted a pitched roof to project the resultant impact of the application of silica-aerogel-incorporated composite cement paste as render on the roof-top surface coupled with the installation of a silica-aerogel-incorporated composite insulation board below the roof tiles on the thermalenergy-efficiency of the roof, based on the annual cooling load and energy savings.

\subsection{Morphology Study and Characterization of the Silica Aerogel Sample}

Morphology of the silica aerogel sample was studied by performing imaging using a Scanning Electron Microscope (SEM) of model Quanta FEG 650 that was manufactured by the FEI Company (Hillsboro, OR, USA). The sample was smeared on a glass plate of the SEM and then scanned. Characterization of the silica aerogel sample was performed by conducting X-Ray Diffraction (XRD) and X-Ray Fluorescence (XRF) analyses to study its crystallographic structure and chemical composition, respectively, and accordingly, ascertain its compatibility when it is incorporated with the other materials. In order to conduct the XRD and XRF analyses, a representative portion of the sample was ground to grains of approximately $20 \mu \mathrm{m}$ size using a motorized grinding machine. The sample for the XRD analysis, which was performed using an X-Ray Diffractometer of model D8 ADVANCE, which was manufactured by Bruker Corporation (Billerica, MA, USA), was prepared by hand-pressing the powdered sample to fill a circular hole, of $25 \mathrm{~mm}$ in diameter, on a sample holder. The surface of the sample was then flattened using a glass slide. On the other hand, the sample for the XRF analysis was prepared by igniting $0.5 \mathrm{~g}$ of the sample at $1050^{\circ} \mathrm{C}$ for $20 \mathrm{~min}$, to remove impurities, before casting the sample into a glass disc of $32 \mathrm{~mm}$ in diameter. The sample was analyzed for 10 major elements using an XRF Spectrometer of model Axios that was manufactured by Malvern Panalytical (Malvern, WO, UK), using the oxides-analysis option, which enabled the detection of oxygen and, accordingly, the elements in their oxidized states. Calibration was conducted using a high-quality, internationally-standardized, and certified reference material, namely rhyolite, whose composition was compared with that of the silica aerogel sample.

\subsection{Preparation of Cement Paste Samples}

Ordinary Portland cement (OPC) and free water were prepared in accordance with the standards defined by the British/European Standard (BS EN), which are BS EN 197-1:2011 [39] and BS EN 1008:2002 [40], respectively. Granular silica aerogel was prepared according to the method introduced by Halimaton Hamdan in 2011 [41]. Cement paste was prepared by mixing the OPC with the free water with a water-cement ratio of 0.5 based on the procedure of the American Society for Testing Materials (ASTM) in ASTM C305-20 [42]. One control cement paste sample without silica aerogel and four silica-aerogel-incorporated composite cement paste samples that contained $2 \mathrm{wt} . \%, 4 \mathrm{wt} . \%, 6 \mathrm{wt} . \%$, and $8 \mathrm{wt} . \%$ of the silica aerogel were prepared and then poured into cube steel molds with dimensions of $50 \mathrm{~mm} \times 50 \mathrm{~mm} \times 50 \mathrm{~mm}$ and left to harden at room temperature for $24 \mathrm{~h}$. Then, the hardened samples were cured in the curing tank for 28 days at the water temperature of $25 \pm 2{ }^{\circ} \mathrm{C}$ in accordance with BS EN 12390-2:2019 [43].

\subsection{Preparation of Composite Insulation Samples}

High-density polyethylene (HDPE) pellets, kapok fiber, and silica aerogel were employed to form samples of a novel composite insulation using the hot pressing technique [44]. The constituent materials were weighed and packed into cavity slots of steel molds, where silica aerogel and kapok fiber were sandwiched in between two layers of HDPE. Two shapes of the samples were formed as shown in Figure 1. The dog-bone shape was adopted to conduct tensile strength tests as per the Type 1 sample mentioned in ASTM D638-14 [45]. The prism shape was adopted to conduct flexural strength tests as per Procedure B as mentioned in ASTM D790-17 [46]. 


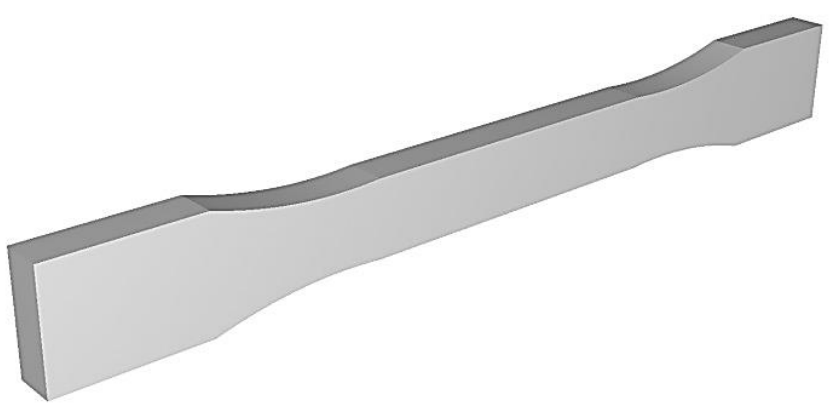

(a)

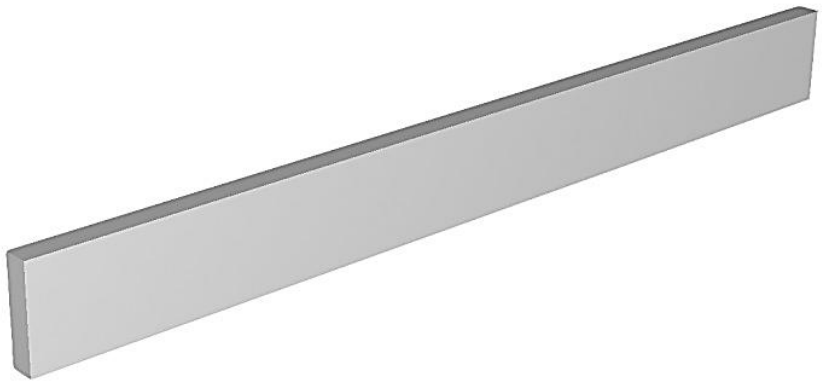

(b)

Figure 1. Shapes of composite insulation samples for the (a) tensile tests (dog-bone) and (b) flexural tests (prism).

A thin layer of wax was applied onto the surface of the mold in advance to ease the process of detaching the samples from the cavity slots. After the cavity slots were filled, the mold was closed by placing a steel cover on top and subsequently, the samples were compressed at $160^{\circ} \mathrm{C}$ using the Hydraulic Laboratory Press of model Monarch CMG $30 \mathrm{H}-15$ that was manufactured by Carver Inc. (Wabash, IN, USA), without applying any pressure for the first five minutes, and subsequently, with a pressure of 120 tons-force for $60 \mathrm{~min}$. Then, the Hydraulic Laboratory Press was switched off and the mold was left to cool for approximately $60 \mathrm{~min}$ until the temperature of the samples decreased to $80^{\circ} \mathrm{C}$. The mold was then removed from the machine, and the samples were detached from the cavity slots, as shown in Figure 2.

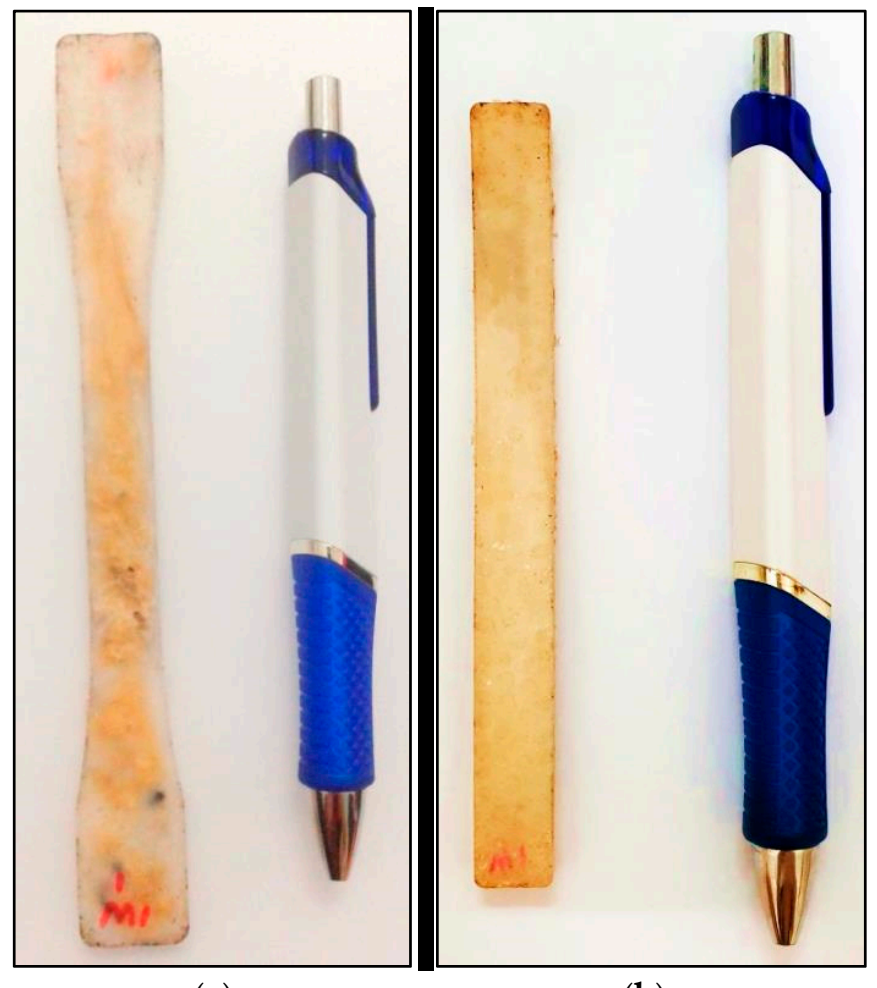

(a)

(b)

Figure 2. Composite insulation samples for the (a) tensile tests (dog-bone) and (b) flexural tests (prism).

\subsection{Compressive Strength and Permeable Porosity Tests on Composite Cement Paste Samples}

Compressive strength tests were conducted on the composite cement paste samples at three, seven and 28 days of curing using the Digital Compression Machine of model ADR Touch SOLO 2000 BS EN manufactured by ELE International (Leighton Buzzard, UK) with a loading rate of $0.9 \mathrm{kN} / \mathrm{s}$. The compressive strength $\left(F_{c}\right)$ indicates the maximum 
compressive load that a sample can withstand before failure $\left(P_{c}\right)$ per unit of cross-sectional area of the sample $(A)$ as shown in Equation (1). An average of five readings was taken as the compressive strength for each type of sample.

$$
F_{c}=\frac{P_{c}}{A}
$$

Permeable porosity tests were also performed on the composite cement paste samples. After 28 days of curing, the samples were dried in the oven at $110{ }^{\circ} \mathrm{C}$ until the mass reduction per $24-\mathrm{h}$ interval did not surpass $1 \%$. The saturated surface-dry mass of the samples in air $\left(W_{s}\right)$, oven-dry mass of the samples in air $\left(W_{d}\right)$, and buoyant mass of the saturated samples in water $\left(W_{b}\right)$ were measured to calculate the permeable porosity $(\phi)$ as shown in Equation (2).

$$
\varphi=\frac{W_{s}-W_{d}}{W_{s}-W_{b}} \times 100 \%
$$

\subsection{Tensile and Flexural Strength Tests on Composite Insulation Samples}

Tensile strength tests were conducted on the composite insulation samples at the room temperature of $23^{\circ} \mathrm{C}$ and relative humidity of 55\% using the Universal Testing Machine (UTM) of model AI-7000S manufactured by GOTECH Testing Machines Inc. (New Castle, DE, USA), with tensile grips. The test was conducted based on the Type 1 sample as mentioned in ASTM D638-14 [45]. The speed adopted to pull the samples, which fall under the semi-rigid category, was $5.00 \mathrm{~mm} / \mathrm{min}$. The tensile strength $\left(F_{t}\right)$ was recorded when the samples have completely failed.

Flexural strength test was conducted for the composite insulation samples at room temperature using the same machine, but, this time, the tensile grips were replaced with a three-point-bend platform. The samples were tested in accordance with Procedure B as mentioned in ASTM D790-17 [46]. The moving crosshead of the machine was set to descend at a constant speed of $21.33 \mathrm{~mm} / \mathrm{min}$ and stopped when the deflection of the sample had reached 5\%, which was when the flexural strength $\left(F_{f}\right)$ was recorded.

\subsection{Thermal Conductivity Test on Composite Cement Paste and Insulation Samples}

Thermal conductivity tests were performed on the composite cement paste and insulation samples. The composite cement paste samples were tested after 28 days of curing. On the other hand, the composite insulation samples were tested after cooling, subsequent to hot-pressing. The tests were conducted using the Thermal Conductivity Analyzer of model TCi manufactured by C-Therm Technologies Ltd. (Queen St. Fredericton, NB, Canada) The method applied was the Modified Transient Plane Source technique in accordance with ASTM D7984-16 [47]. An average of five readings of thermal conductivity $(k)$ that were taken at one-minute intervals was adopted for each sample to ascertain the stability of the reading.

\subsection{Simulation Study on Building Information Model (BIM) with Pitched Roof}

A simulation study was performed on a BIM, which was employed previously in Farhan et al. [38] for a different study, to project the resultant impact of the silica-aerogelincorporated cement paste as render on the roof-top surface, coupled with the silica-aerogelincorporated composite insulation board installed below the roof tiles, on the annual cooling load and energy savings. The BIM was created in Integrated Environmental Solutions $<$ Virtual Environment $>$ (IES <VE $>$ ) using its ModelIT module, as shown, in axonometric view, in Figure 3. The dimensions of the BIM were $4 \mathrm{~m}$ width, $4 \mathrm{~m}$ length and $3 \mathrm{~m}$ height, and they were determined as such to fulfill the minimum requirements of a habitable room in Malaysia as per the Uniform Building By-Laws 1984 [48]. The materials assigned to the BIM were adopted based on the materials employed in Farhan et al. [38]. The simulation data generated from the BIM in IES $<$ VE $>$ were already validated in Farhan et al. [38] against the data collected from test cells located in Universiti Teknologi MARA, Shah 
Alam, Malaysia, which were also employed in previous studies by Irwan et al. [49,50], Halim et al. [51], Morris et al. [52,53], and Zakaria et al. [54]. Correspondingly, the location of Shah Alam, Malaysia, was also selected as the location of the BIM in the present study, as Shah Alam is subjected to a tropical climate and, hence, exposed to intense and prolonged solar radiation, as well as high amounts of rainfall.

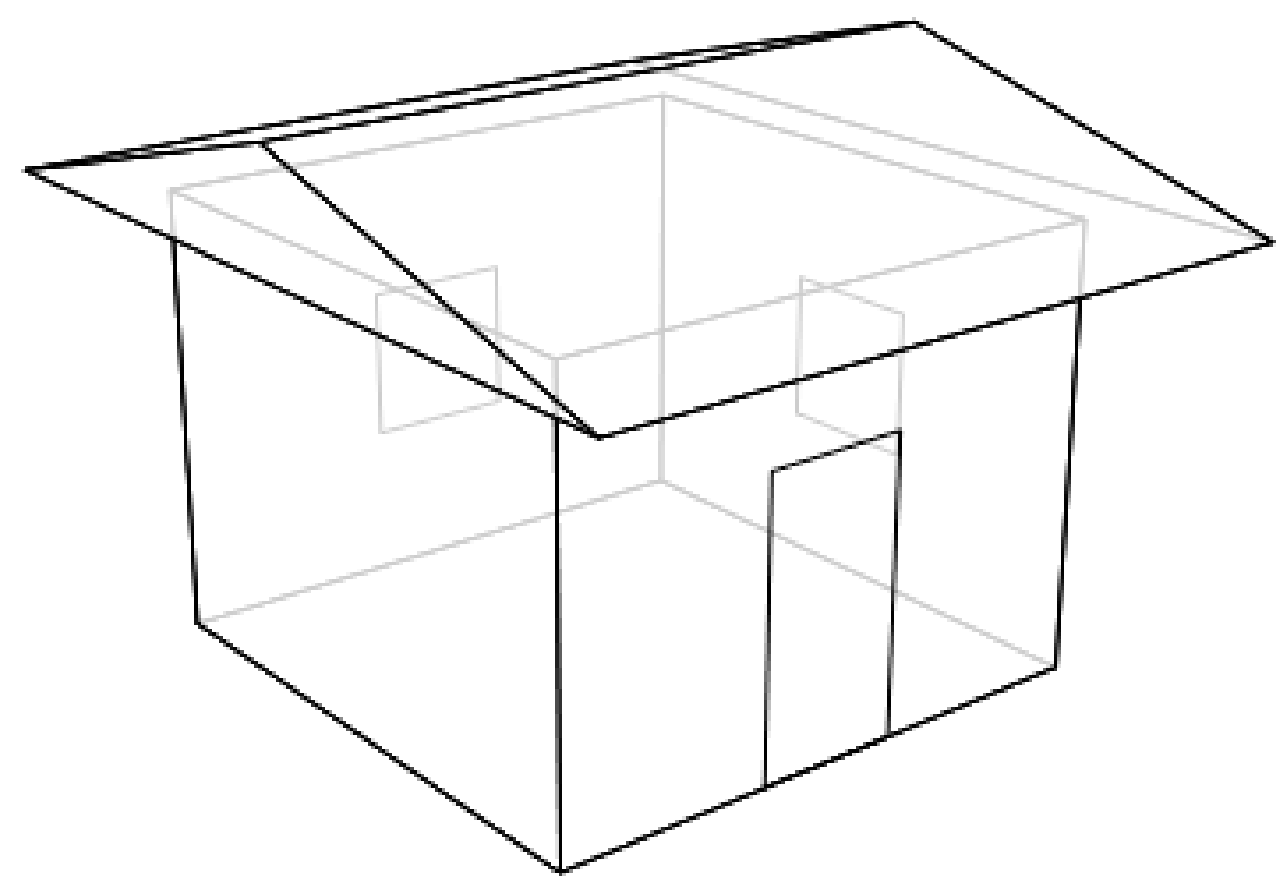

Figure 3. Axonometric view of the Building Information Model.

The thermal conductivity values of the silica-aerogel-incorporated samples with optimum amounts of silica aerogel, which were determined from the results of the thermal and strength performance tests, were assigned to the modeled layer of the silica-aerogelincorporated composite cement paste that was applied as render on the roof-top surface, and the modeled layer of the silica-aerogel-incorporated composite insulation board that was installed below the roof tiles, which were embedded in the BIM using the ModelIT module of IES $<\mathrm{VE}>$. The ApacheSim module of IES $<\mathrm{VE}>$ was then employed to project the annual cooling load and, accordingly, calculate annual energy savings. The configuration of the roof was varied based on the presence of the render on the roof-top surface and composite insulation board below the roof tiles, as well as the thickness of the composite insulation board. Accordingly, five roof configurations were employed for the simulation study, which are presented in Table 1. The thickness of the composite insulation board was varied at $100 \mathrm{~mm}, 200 \mathrm{~mm}$, and $300 \mathrm{~mm}$, while the thickness of the cement render coated on the roof tiles was fixed at $20 \mathrm{~mm}$ in accordance with conventional practices.

Table 1. Roof configurations of the BIM employed for the simulation study.

\begin{tabular}{ccc}
\hline $\begin{array}{c}\text { BIM Roof } \\
\text { Configuration ID }\end{array}$ & $\begin{array}{c}\text { Presence of Cement Render } \\
\text { on the Roof-Top Surface }\end{array}$ & $\begin{array}{c}\text { Presence and Thickness of } \\
\text { Roof Insulation Material }\end{array}$ \\
\hline$C$ & Without cement render & $\begin{array}{c}\text { Without insulation } \\
\text { Without insulation }\end{array}$ \\
$R$ & With cement render & $\begin{array}{c}\text { With 100-mm thick composite } \\
\text { insulation board } \\
\text { With 200-mm thick composite } \\
\text { insulation board }\end{array}$ \\
$R 200$ & $\begin{array}{c}\text { With 300-mm thick composite } \\
\text { insulation board }\end{array}$ \\
\hline
\end{tabular}




\section{Results and Discussion}

\subsection{Morphology Study of the Silica Aerogel Sample}

The SEM image of the silica aerogel sample at 50,000 $\times$ magnification is presented in Figure 4. The image indicates that the sample has no definite form, with the silica particles forming aggregates with each other. It has a porous structure with the aggregates formed by spherical particles, with an average size of $54.77 \mathrm{~nm}$.

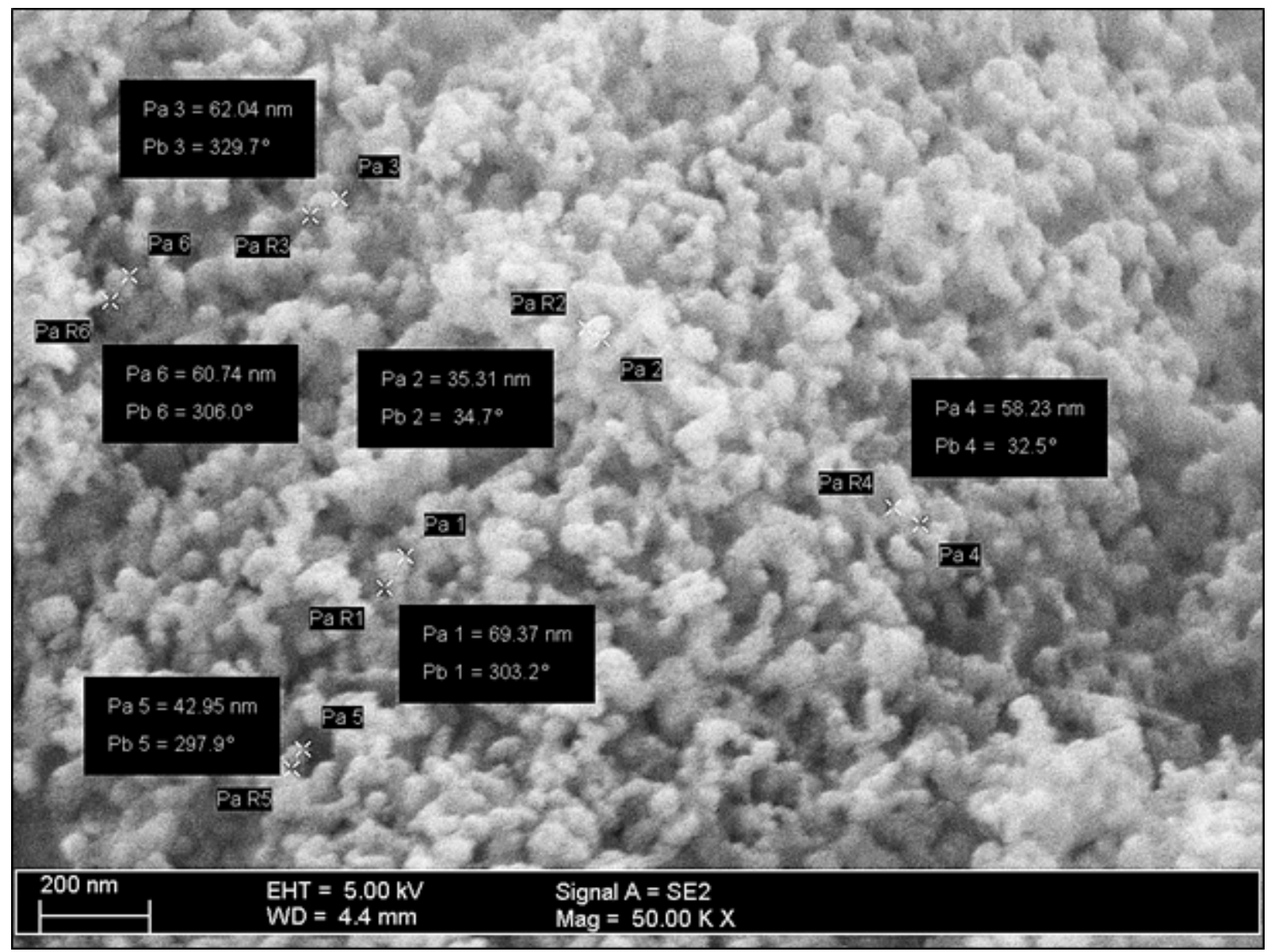

Figure 4. SEM image of the silica aerogel sample at 50,000× magnification.

\subsection{Characterization of Silica Aerogel Sample}

The XRD pattern of the silica aerogel sample as shown in Figure 5 reveals the presence of humps at the low-angle region together with narrow and sharp peaks, hence indicating that the sample is moderately amorphous. Furthermore, the analysis revealed the presence of silica gel as the main constituent, as well as thenardite, which is an anhydrous sodium sulfate $\left(\mathrm{Na}_{2} \mathrm{SO}_{4}\right)$, as indicated by the red line.

Table 2 shows the composition of the silica aerogel sample obtained from the XRF analysis and reveals that, among all of the oxides, the silicon dioxide $\left(\mathrm{SiO}_{2}\right)$ content is the highest, which is $74.48 \%$. The high $\mathrm{SiO}_{2}$ content, coupled with the amorphous state of the particles, imparts an ultra-low thermal conductivity to the silica aerogel. Other than $\mathrm{SiO}_{2}$, sodium oxide $\left(\mathrm{Na}_{2} \mathrm{O}\right)$ was also present in the sample, with a content of $9.15 \%$. The presence of oxides other than $\mathrm{SiO}_{2}$ was due to the presence of impurities, owing to the sample being mixed with the residue from other samples during preparation and heat treatment [55]. 


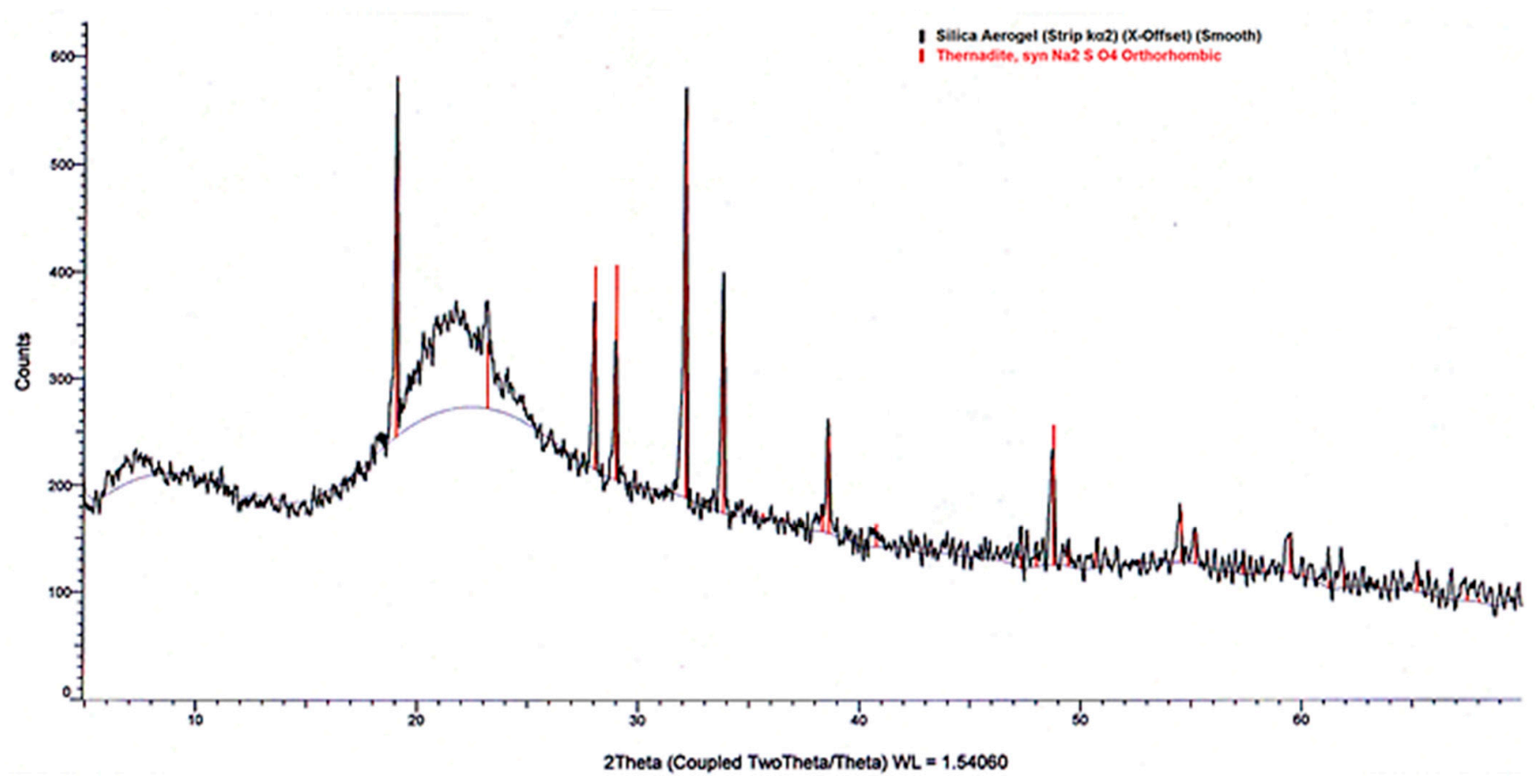

Figure 5. X-Ray Diffraction (XRD) pattern of the silica aerogel sample.

Table 2. Composition of the silica aerogel sample obtained from the X-Ray Fluorescence (XRF) analysis.

\begin{tabular}{cc}
\hline Oxides & Content (wt.\%) \\
\hline Silicon Dioxide $\left(\mathrm{SiO}_{2}\right)$ & 74.48 \\
Sodium Oxide $\left(\mathrm{Na}_{2} \mathrm{O}\right)$ & 9.15 \\
Aluminium Oxide $\left(\mathrm{Al}_{2} \mathrm{O}_{3}\right)$ & 0.05 \\
Calcium Oxide $\left(\mathrm{CaO}^{2}\right)$ & 0.05 \\
Iron (III) Oxide $\left(\mathrm{Fe}_{2} \mathrm{O}_{3}\right)$ & 0.05 \\
Magnesium Oxide $(\mathrm{MgO})$ & 0.01 \\
Manganese $(\mathrm{II})$ Oxide $(\mathrm{MnO})$ & 0.01 \\
Titanium $(\mathrm{IV})$ Oxide $\left(\mathrm{TiO}_{2}\right)$ & Below detection limit \\
\hline
\end{tabular}

\subsection{Thermal and Strength Performances of Composite Cement Paste Samples}

Figure 6 presents the $F_{c}$ and $k$, at 28 days of curing, of the composite cement paste samples that contained varying silica aerogel content. $F_{c}$ decreased from $49.28 \mathrm{MPa}$ to 42.89 MPa when the silica aerogel content per sample was increased from $0 \mathrm{wt} . \%$ to $2 \mathrm{wt} . \%$. Conversely, a further addition of $2 \mathrm{wt}$.\% of silica aerogel per sample, which was from $2 \mathrm{wt} . \%$ to $4 \mathrm{wt} . \%$, led to the culmination of $F_{c}$ at its highest value of $54.33 \mathrm{MPa}$. As the silica aerogel content was increased from $4 \mathrm{wt} . \%$ to $6 \mathrm{wt} . \%$ and then $8 \mathrm{wt} . \%, F_{c}$ was adversely affected, where $F_{c}$ decreased from 54.33 MPa to 47.03 MPa and then its lowest value of 34.77 MPa, respectively. A similar trend of $F_{c}$ was reported in Bostanci et al. [56]. Furthermore, it can be projected that the adverse effect on $F_{c}$ will extend as higher amounts of silica aerogel are incorporated, as revealed in $\mathrm{Ng}$ et al. [57]. In essence, the incorporation of $8 \mathrm{wt} . \%$ of silica aerogel led to a loss of strength of $29.44 \%$, where $F_{c}$ decreased from $49.28 \mathrm{MPa}$ to $34.77 \mathrm{MPa}$. On the other hand, the incorporation of silica aerogel led to a drop in $k$ from $1.185 \mathrm{~W} / \mathrm{mK}$ to $0.340 \mathrm{~W} / \mathrm{mK}, 0.142 \mathrm{~W} / \mathrm{mK}, 0.086 \mathrm{~W} / \mathrm{mK}$, and $0.076 \mathrm{~W} / \mathrm{mK}$ when 2 wt. $\%, 4$ wt. $\%, 6$ wt. $\%$, and $8 \mathrm{wt} . \%$ of silica aerogel were incorporated, respectively. Essentially, the incorporation of $8 \mathrm{wt}$.\% of silica aerogel resulted in a decline in $k$ of $93.59 \%$, with a gradient that decreased as the silica aerogel content was increased. In view of the culmination of $F_{c}$ at its highest value of $54.33 \mathrm{MPa}$ that coincides with the conspicuous decrease in the gradient of $k$ as it declined from $1.185 \mathrm{~W} / \mathrm{mK}$ to $0.142 \mathrm{~W} / \mathrm{mK}$, it can be deduced that the silica aerogel content of $4 \mathrm{wt}$.\% resulted in the optimum formulation of the silica-aerogel-incorporated composite cement paste. 


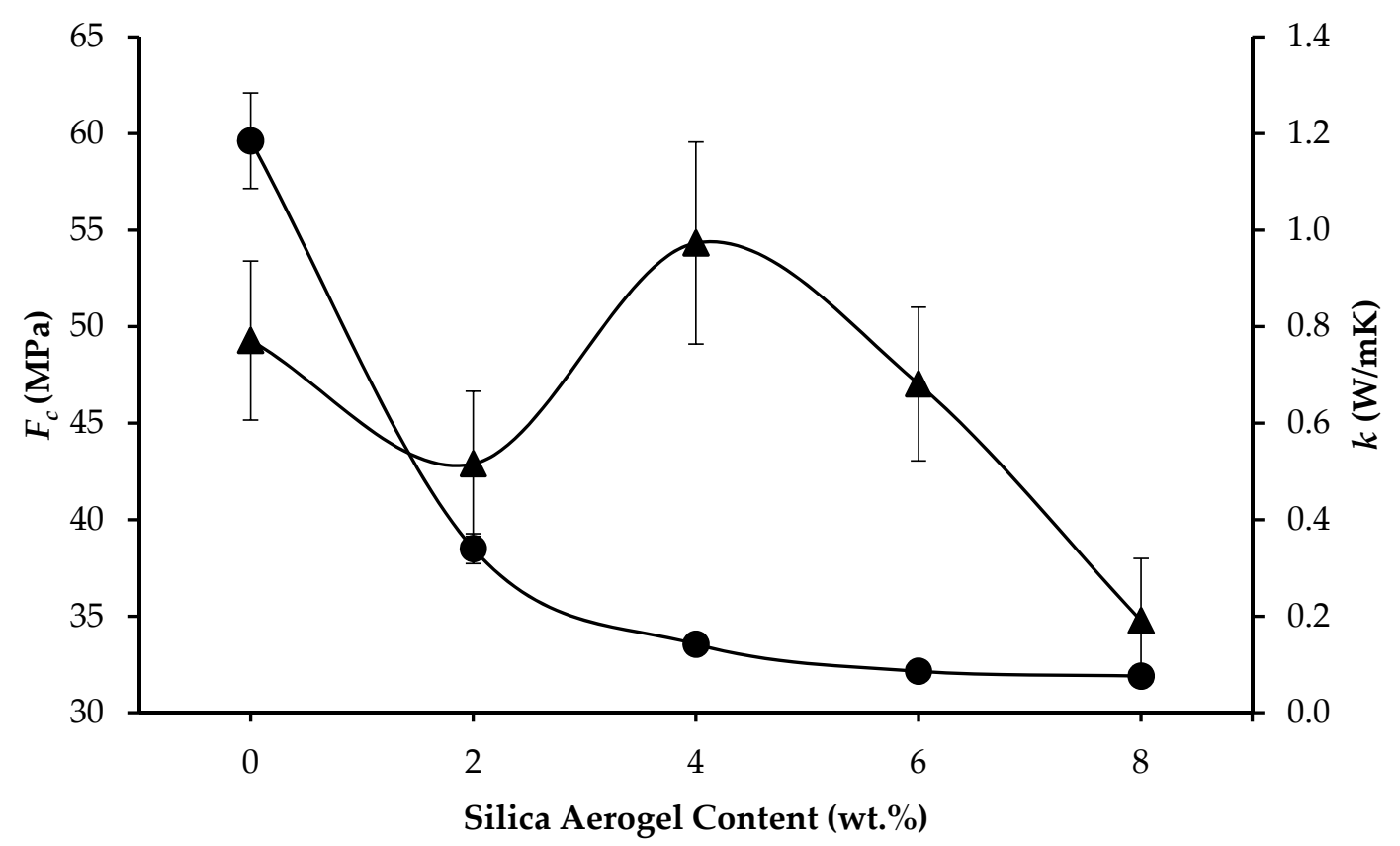

$\longrightarrow$ Compressive Strength $\longrightarrow$ - Thermal Conductivity

Figure 6. Compressive strength $\left(F_{c}\right)$ and thermal conductivity $(k)$ of the composite cement paste after 28 days of curing.

Figure 7 shows that the increase in the silica aerogel content in the composite cement paste increased its $\phi$, which was due to the nano-sized pore structure of silica aerogel. The $\phi$ of the cement paste, without the incorporation of silica aerogel, was $0.128 \%$. The incorporation of $2 \mathrm{wt} . \%$ of silica aerogel in the cement paste induced a rise in $\phi$ from $0.128 \%$ to $0.160 \%$. Further addition of silica aerogel from $2 \mathrm{wt} . \%$ to $4 \mathrm{wt} . \%, 6 \mathrm{wt} . \%$, and $8 \mathrm{wt} . \%$ led to the increase in $\phi$ to $0.220 \%, 0.216 \%$, and $0.256 \%$, respectively. The increase in the silica aerogel content beyond $4 \mathrm{wt} . \%$ led to the sharp decline in $F_{c}$ from $54.33 \mathrm{MPa}$ to $34.77 \mathrm{MPa}$ due to the high $\phi$ of $0.256 \%$. However, when the silica aerogel content was increased from $2 \mathrm{wt} . \%$ to its optimum value of $4 \mathrm{wt} . \%$, the $F_{c}$ improved from $42.89 \mathrm{MPa}$ to $54.33 \mathrm{MPa}$ in spite of the increase in porosity from $0.160 \%$ to $0.220 \%$.

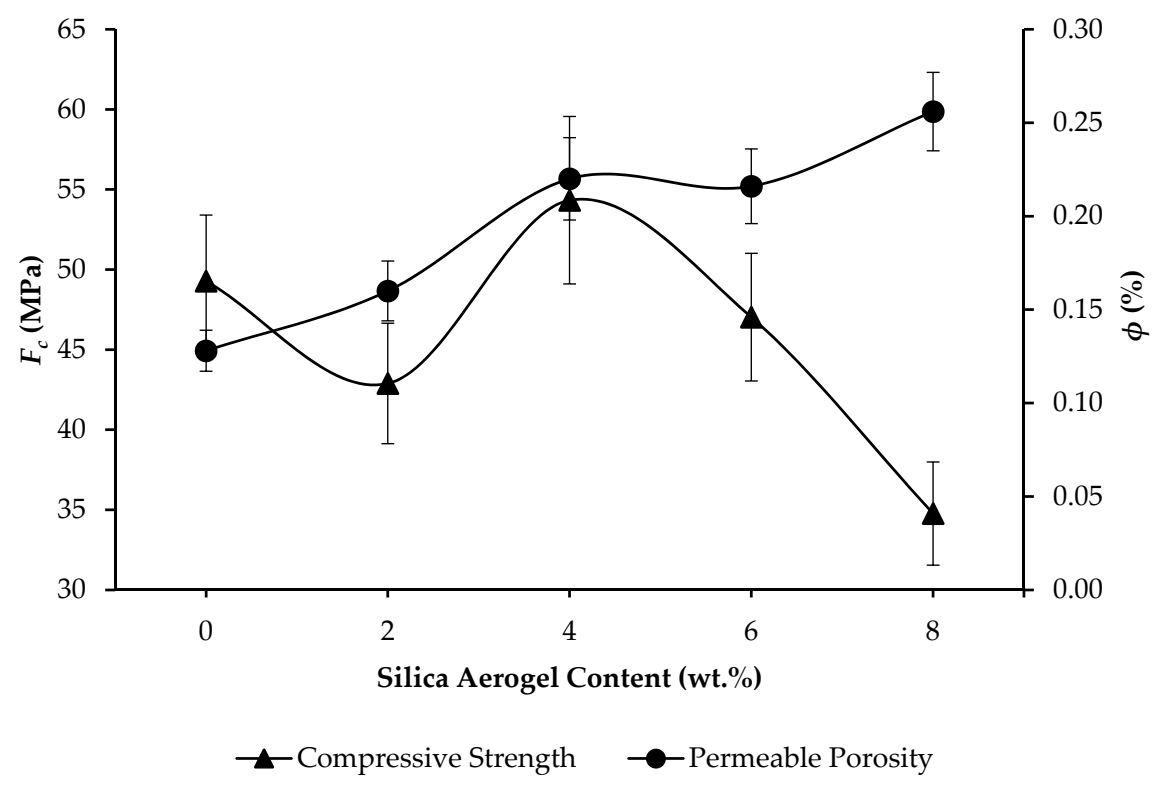

Figure 7. Compressive strength $\left(F_{c}\right)$ and permeable porosity $(\phi)$ of the composite cement paste after 28 days of curing. 


\subsection{Thermal and Strength Performances of Composite Insulation Samples}

Figure 8 presents the $F_{t}$ and $k$ of the composite insulation samples that contained varying silica aerogel content. The highest $F_{t}$ of $11.58 \mathrm{MPa}$ was obtained for the composite insulation sample that was not incorporated with silica aerogel. The $F_{t}$ decreased sharply to $7.04 \mathrm{MPa}$ when $1 \mathrm{wt} . \%$ of silica aerogel was added. Contrarily, further increments in the silica aerogel content from $1 \mathrm{wt} . \%$ to $2 \mathrm{wt} . \%$, and then $3 \mathrm{wt} . \%$, resulted in the improvement of $F_{t}$ from $7.04 \mathrm{MPa}$ to $8.24 \mathrm{MPa}$, and then $8.74 \mathrm{MPa}$, respectively. However, further additions of silica aerogel beyond $3 \mathrm{wt} . \%$ induced a decline in $F_{t}$ from $8.74 \mathrm{MPa}$ to $7.18 \mathrm{MPa}$, and then $6.47 \mathrm{MPa}$, for the samples with silica aerogel contents of $4 \mathrm{wt}$.\% and $5 \mathrm{wt} . \%$, respectively, due to the agglomeration of the silica aerogel particles, which affected the strength and elongation of the sample, according to Zolfaghari et al. [58] and Thongpin et al. [59]. As for $k$, a gradual decrease was observed with each increment in silica aerogel content. The sample that was not incorporated with silica aerogel obtained the highest $k$ of $0.20 \mathrm{~W} / \mathrm{mK}$, which then declined to $0.15 \mathrm{~W} / \mathrm{mK}, 0.14 \mathrm{~W} / \mathrm{mK}, 0.09 \mathrm{~W} / \mathrm{mK}$, $0.06 \mathrm{~W} / \mathrm{mK}$, and then $0.04 \mathrm{~W} / \mathrm{mK}$ when the silica aerogel content was increased to $1 \mathrm{wt} . \%$, $2 \mathrm{wt.} \%, 3 \mathrm{wt} . \%$, $4 \mathrm{wt} . \%$, to $5 \mathrm{wt} . \%$, respectively, with a percentage in overall decline of $80 \%$.

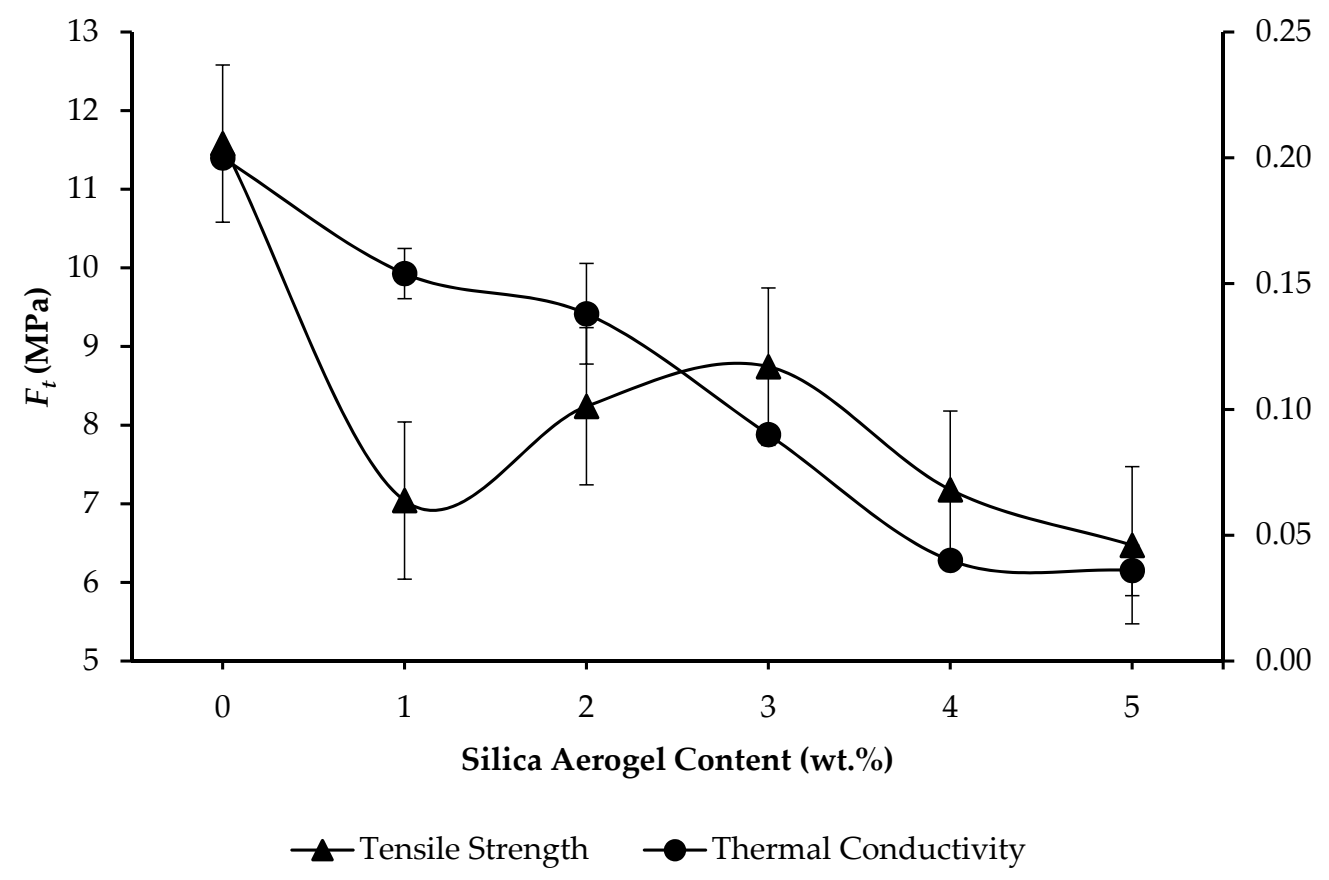

Figure 8. Tensile strength $\left(F_{t}\right)$ and thermal conductivity $(k)$ for the composite insulation materials.

Figure 9 shows the $F_{f}$ and $k$ of the composite insulation samples that contained varying silica aerogel content. The highest $F_{f}$ of $23.24 \mathrm{MPa}$ was obtained for the control sample, which was not incorporated with silica aerogel. Increment of silica aerogel from $0 \mathrm{wt} . \%$ to $1 \mathrm{wt} . \%$ resulted in a decrease of $F_{f}$ from $23.24 \mathrm{MPa}$ to $18.96 \mathrm{MPa}$. Conversely, the $F_{f}$ increased from 18.96 MPa to $19.88 \mathrm{MPa}$, and then $21.37 \mathrm{MPa}$, when the silica aerogel content was increased from $1 \mathrm{wt} . \%$, to $2 \mathrm{wt} . \%$, and then to $3 \mathrm{wt} . \%$, respectively. Subsequently, the $F_{f}$ decreased from $21.37 \mathrm{MPa}$, to $18.63 \mathrm{MPa}$, and then to the lowest $F_{f}$ of $17.64 \mathrm{MPa}$ when the silica aerogel content was increased from $3 \mathrm{wt} . \%$, to $4 \mathrm{wt} . \%$, and then to the highest silica aerogel content of $5 \mathrm{wt} . \%$, which is due to the high $\phi$ of the silica aerogel that resulted in its lower mechanical performance as mentioned in Wucherer et al. [60], and also the impact of further adding silica aerogel that tends to reaggregate instead of spreading homogeneously throughout the HDPE-kapok fiber matrix [61], leading to a decrease in the interaction between the surface area of the silica aerogel with the HDPE and kapok fiber as highlighted in Mazlan et al. [62], and, as a consequence, caused the sample to be more brittle due to ineffective stress transfer. Although $k$ greatly decreased with the incorporation of silica 
aerogel in the composite insulation, the silica aerogel content of $3 \mathrm{wt} . \%$ is recommended to formulate a composite insulation that concurrently possesses low $k$ with reasonably high $F_{t}$ and $F_{f}$.

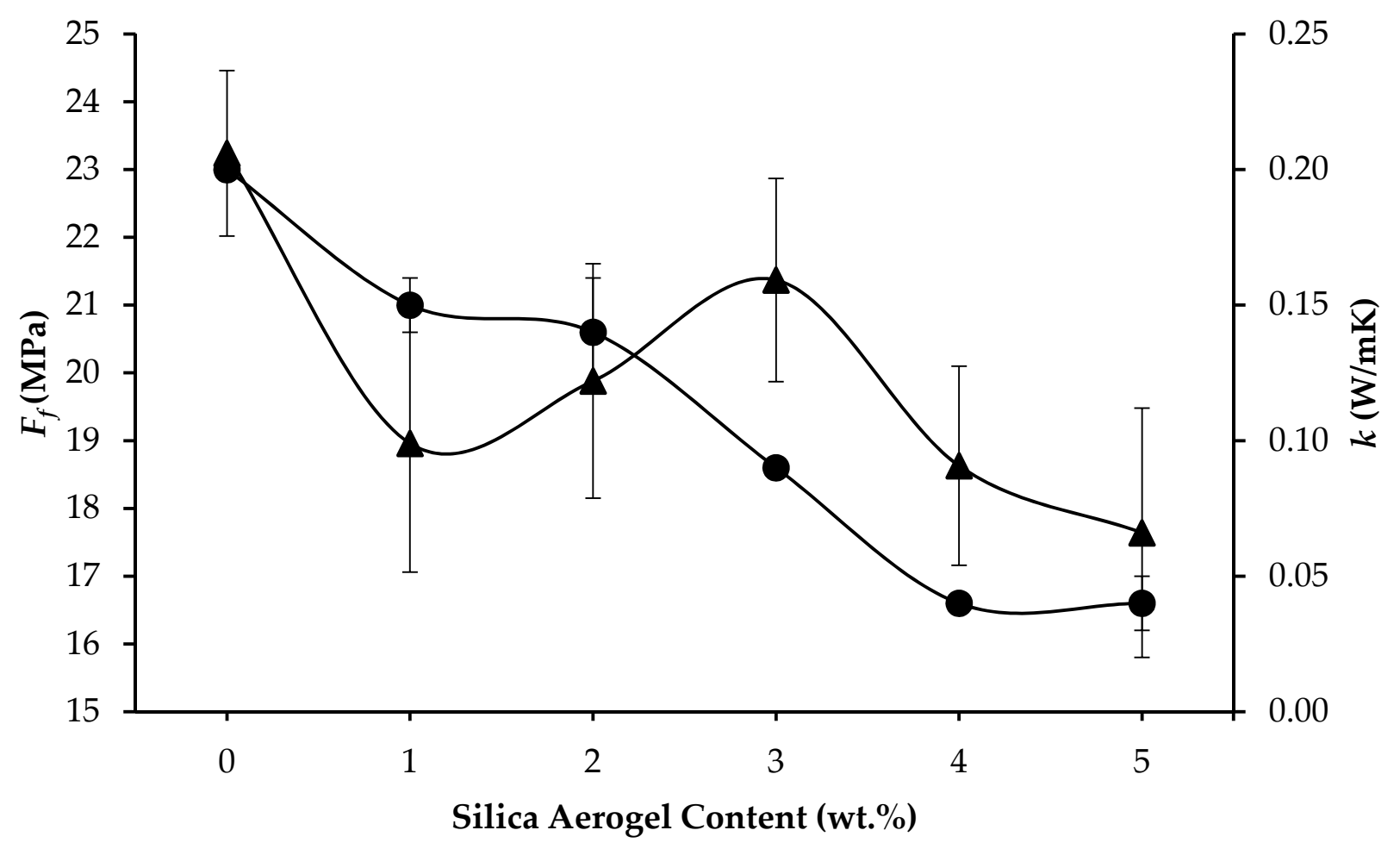

\section{—Flexural Strength $\quad \longrightarrow$-Thermal Conductivity}

Figure 9. Flexural strength $\left(F_{f}\right)$ and thermal conductivity $(k)$ for the composite insulation samples.

Unlike tensile strength tests where stress is distributed along the sample, the stress in flexural strength test is more restricted to the region of the applied load. Figure 10 compares the $F_{t}$ and $F_{f}$ profiles of the composite insulation samples with varying silica aerogel content. Notwithstanding the minor difference between the gradient of the declines of $F_{t}$ and $F_{f}$ when the silica aerogel content was increased from $0 \mathrm{wt}$. \% to $1 \mathrm{wt} . \%$, where the decline of $F_{t}$ was sharper than that of $F_{f}$, profiles of $F_{t}$ and $F_{f}$ exhibited similar trends and is in agreement with the findings in Shahroze et al. [63], hence validating the consistency in the preparation of corresponding samples that were employed to perform the tensile and flexural strength tests.

\subsection{Thermal-Energy Performance of BIM with Pitched Roof}

Figures 11-13 reveal the direct, diffused and global solar radiation fluxes that the BIM were subjected to throughout the Typical Meteorological Year (TMY) at the location of Shah Alam, Malaysia, as previously adopted in Farhan et al. [38]. The highest fluxes recorded throughout the TMY for the direct, diffused, and global solar radiation were $965 \mathrm{~W} / \mathrm{m}^{2}$, $540 \mathrm{~W} / \mathrm{m}^{2}$, and $1120 \mathrm{~W} / \mathrm{m}^{2}$, respectively. 


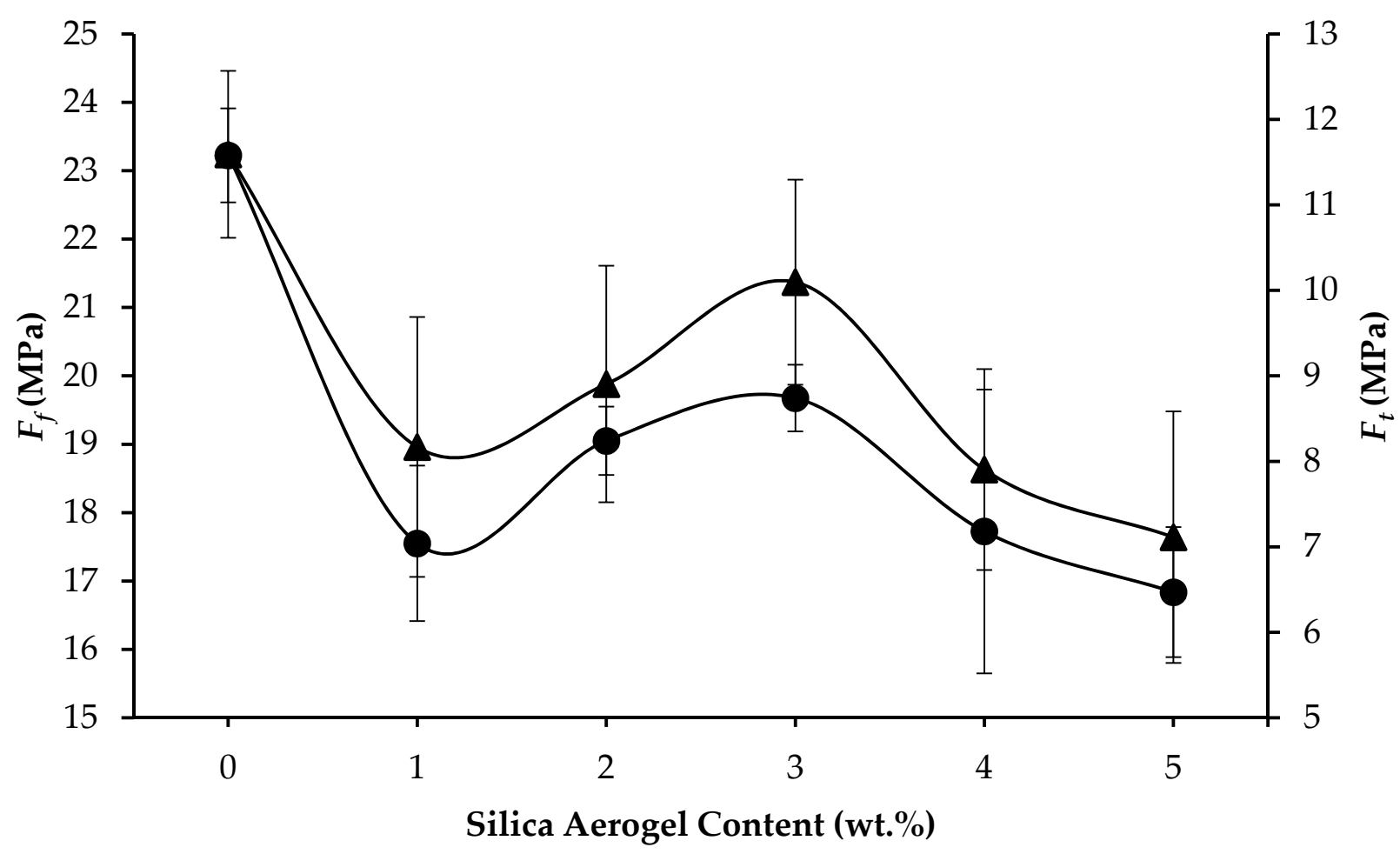

-Flexural Strength $\rightarrow$-Tensile Strength

Figure 10. Flexural strength $\left(F_{f}\right)$ and tensile strength $\left(F_{t}\right)$ for the composite insulation materials.

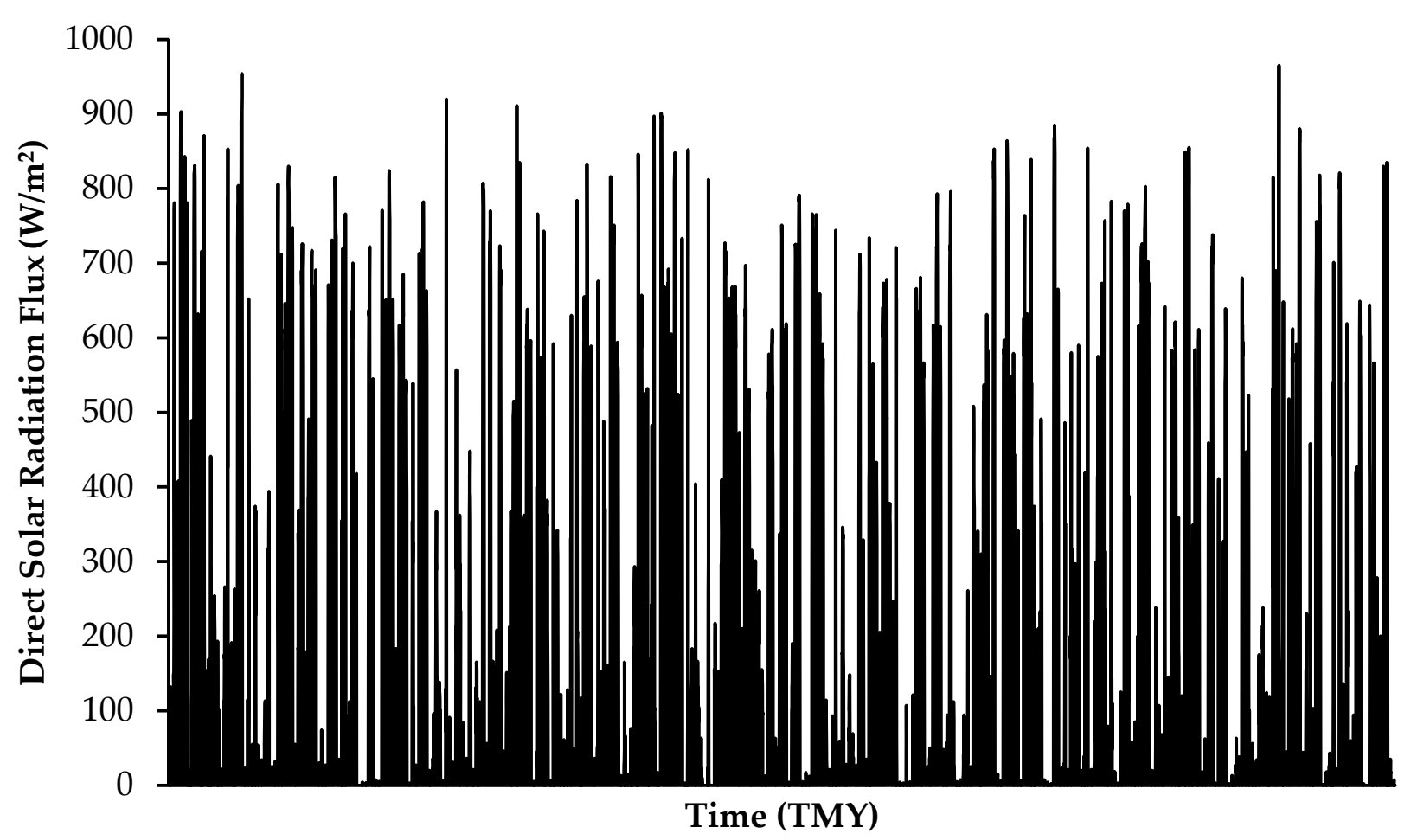

Figure 11. Direct solar radiation flux throughout the Typical Meteorological Year (TMY) at the location of the BIM. 


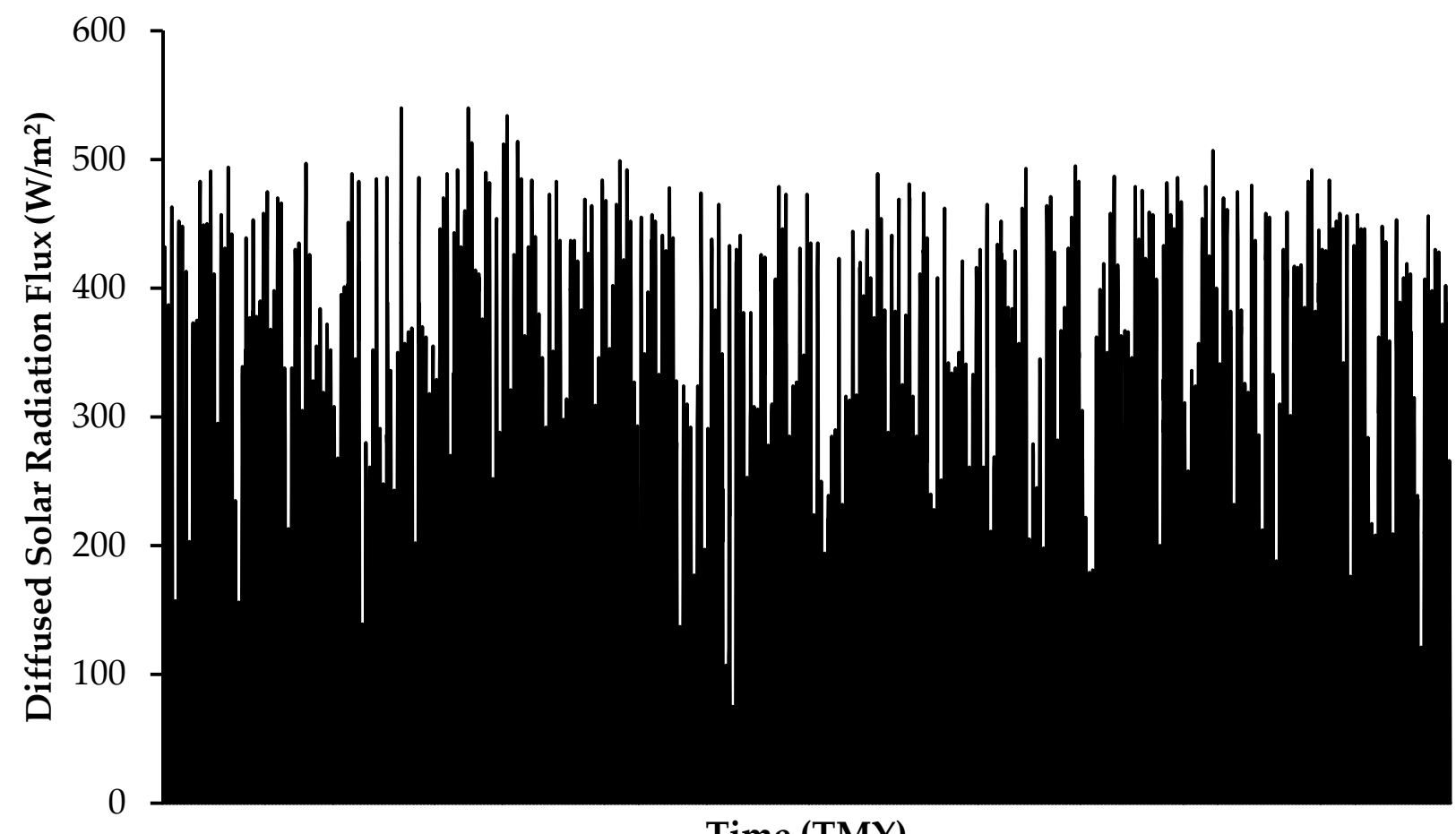

Time (TMY)

Figure 12. Diffused solar radiation flux throughout the TMY at the location of the BIM.

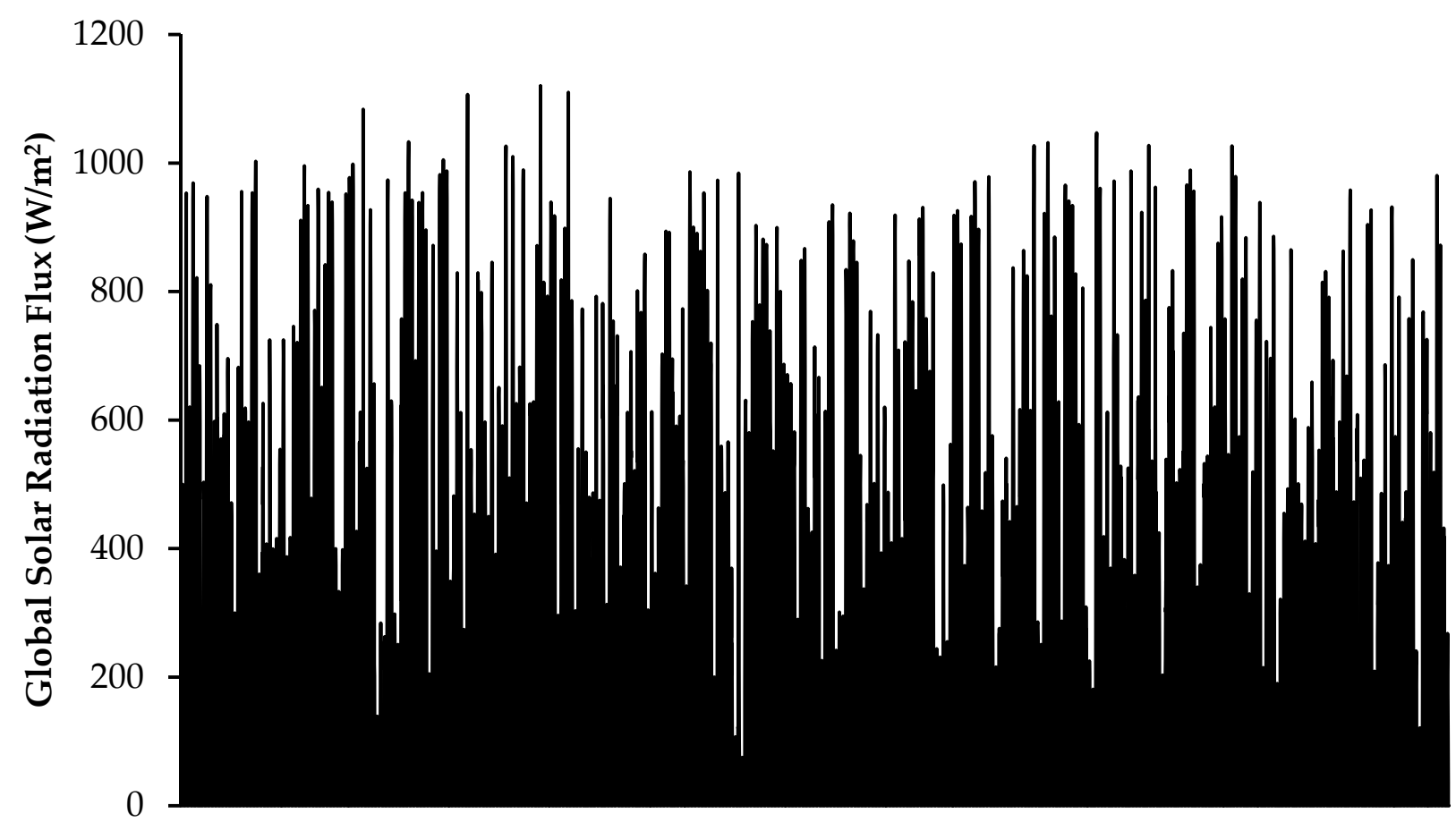

Time (TMY)

Figure 13. Global solar radiation flux throughout the TMY at the location of the BIM.

Figure 14 reveals the annual cooling load and energy savings of the indoor environment of the BIM at varying roof configurations of $C, R, R 100, R 200$, and $R 300$. The annual cooling load of $C$ was $2.6671 \mathrm{MWh}$, and it was marginally reduced to 2.6488 MWh when the 20-mm silica-aerogel-incorporated composite cement paste was applied as render on the roof-top surface to form $R$, hence generating an annual energy savings of $0.6909 \%$. Furthermore, when a 100-mm thick silica-aerogel-incorporated composite insulation board 
was installed below the roof tiles of $R$ to form $R 100$, a sharp drop in the annual cooling load to $2.3903 \mathrm{MWh}$, with an annual energy savings of $11.5801 \%$ relative to $C$, was observed. Additional increments to the thickness of the insulation board to $200 \mathrm{~mm}$, and then $300 \mathrm{~mm}$, resulted in further reductions in the annual cooling load to $2.3491 \mathrm{MWh}$, and then $2.3319 \mathrm{MWh}$, with annual energy savings of, relative to $C, 13.5371 \%$, and then $14.3745 \%$, respectively. The highest gradients, based on their absolute values, in the decline in the annual cooling load, and the rise in the annual energy savings, were observed when the $100-\mathrm{mm}$ thick insulation board was installed to $R$. Therefore, the application of the 20-mm cement render, coupled with the installation of the 100-mm thick insulation board, is recommended as the optimum roof configuration.

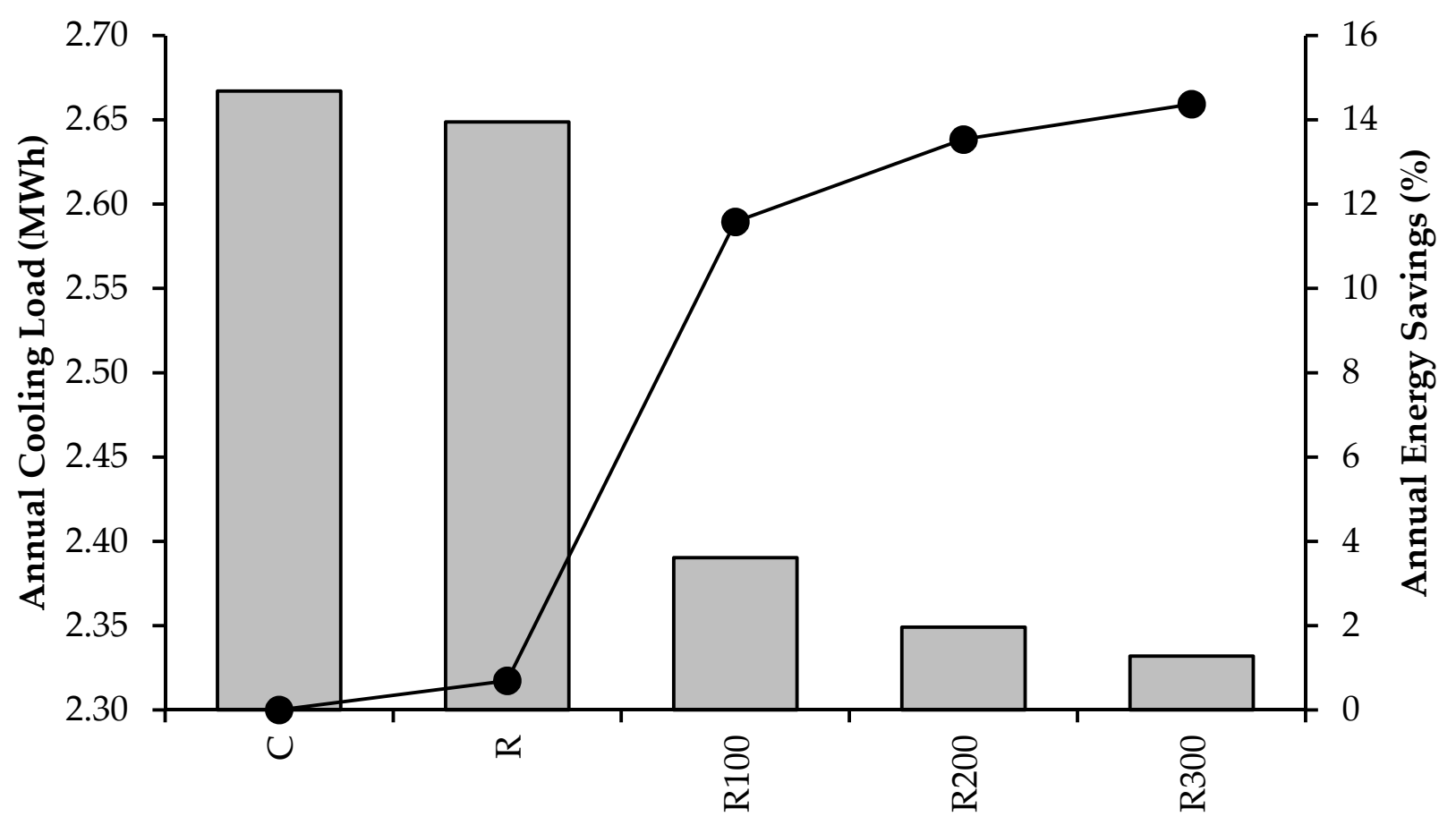

Roof Configuration

$\square$ Cooling Load - $\multimap$ Energy Savings

Figure 14. Annual cooling load and energy savings of the BIM at varying roof configurations.

\section{Conclusions}

The installation of a novel silica-aerogel-incorporated composite insulation board in the roof, coupled with the application of silica-aerogel-incorporated composite cement paste as render on the roof-top surface, was studied to explore the prospect of adopting nanoporous silica-aerogel-incorporated composite materials in thermal-energy-efficient pitched roof assemblies in the tropical region. A morphology study on a silica aerogel sample revealed that the sample had no definite form and a porous structure. Characterization of the sample revealed that the sample was moderately amorphous, with silica gel as the main constituent, where the $\mathrm{SiO}_{2}$ content was the highest, which was $74.48 \%$. Then, $50 \mathrm{~mm} \times 50 \mathrm{~mm} \times 50 \mathrm{~mm}$ cement paste cubes were prepared with OPC and free water, where a control sample without silica aerogel and four silica-aerogel-incorporated samples with varying silica aerogel content were prepared. Composite insulation samples were prepared with HDPE and kapok fiber, where a control sample without silica aerogel and five silica-aerogel-incorporated samples with varying silica aerogel content were prepared. For optimization of thermal and strength performances, the silica aerogel contents of $4 \mathrm{wt} . \%$ and $3 \mathrm{wt} . \%$ were selected for the cement render and insulation board, respectively. A simulation study performed on a BIM with a pitched roof to project annual cooling load and 
energy savings of its indoor environment revealed that the application of 20-mm cement render, coupled with the installation of a 100-mm thick insulation board, is recommended as the optimum roof configuration.

Author Contributions: Conceptualization, S.A.F.; methodology, F.I.I.; software, S.U.A.; validation, N.H.; formal analysis, M.T.S.; investigation, N.H.; resources, F.I.I; data curation, M.T.S.; writingoriginal draft preparation, S.A.F.; writing-review and editing, F.I.I., A.K.V.; visualization, S.U.A.; supervision, N.S.; project administration, N.S.; funding acquisition, N.S. All authors have read and agreed to the published version of the manuscript.

Funding: The APC was funded by Yayasan Universiti Teknologi PETRONAS, Malaysia, via grant number 015LC0-155, as administered by Research Management Center of Universiti Teknologi PETRONAS.

Institutional Review Board Statement: Not applicable.

Informed Consent Statement: Not applicable.

Data Availability Statement: The data presented in this study are available on request from the corresponding author, S.A.F.

Acknowledgments: The authors are thankful to Azni Zain binti Ahmed and team of the Institute of Science of Universiti Teknologi MARA Shah Alam, Malaysia, as well as the team members of Syed Uthman Expert Systems (SUES) (003032518-D), for the support and collaboration.

Conflicts of Interest: The authors declare no conflict of interest.

\section{Nomenclature}

$\begin{array}{ll}\text { Abbreviations } & \\ \text { ASTM } & \text { American Society for Testing Materials } \\ \text { BIM } & \text { Building Information Model } \\ \text { BS EN } & \text { British/European Standard } \\ \text { CFD } & \text { Computational Fluid Dynamics } \\ \text { HDPE } & \text { High-Density Polyethylene } \\ \text { IES<VE }> & \text { Integrated Environmental Solutions }<\text { Virtual Environment }> \\ \text { OPC } & \text { Ordinary Portland Cement } \\ \text { SEM } & \text { Scanning Electron Microscope } \\ \text { TMY } & \text { Typical Meteorological Year } \\ \text { UTM } & \text { Universal Testing Machine } \\ \text { XRD } & \text { X-Ray Diffraction } \\ \text { XRF } & \text { X-Ray Fluorescence } \\ \text { Chemical Formulae } & \\ \mathrm{Al} 2 \mathrm{O} 3 & \text { Aluminium Oxide } \\ \mathrm{CaO} & \text { Calcium Oxide } \\ \text { Fe2O3 } & \text { Iron (III) Oxide } \\ \mathrm{MgO} & \text { Magnesium Oxide } \\ \mathrm{MnO} & \text { Manganese (II) Oxide } \\ \mathrm{Na2O} & \text { Sodium Oxide } \\ \mathrm{Na2SO} 4 & \text { Sodium Sulfate } \\ \mathrm{SiO} 2 & \text { Silicon Dioxide } \\ \mathrm{TiO} 2 & \text { Titanium (IV) Oxide } \\ \mathrm{Notations} & \\ A & \text { Cross-sectional area } \\ \text { C } & \text { Conventional BIM roof configuration without render and insulation } \\ F_{c} & \text { Compressive strength } \\ F_{f} & \text { Flexural strength } \\ \end{array}$




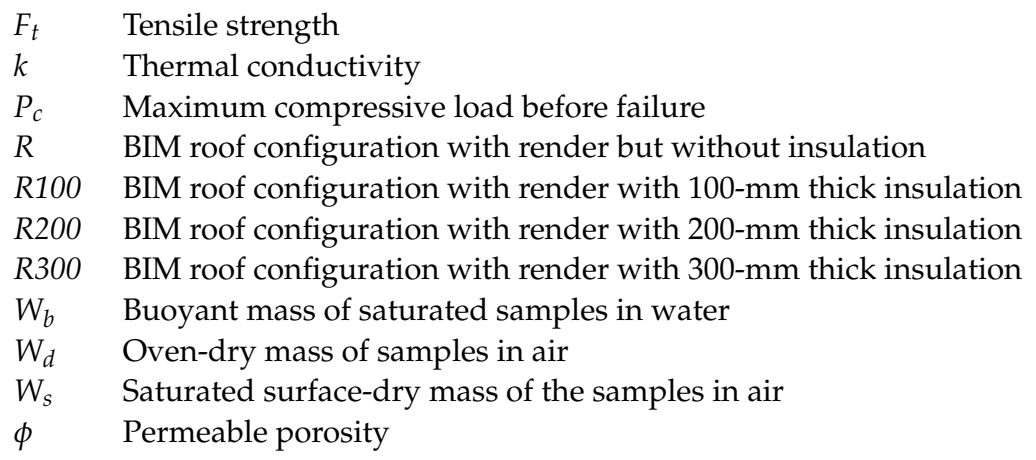

\section{References}

1. Kistler, S.S. Coherent expanded aerogels and jellies. Nature 1931, 127, 741. [CrossRef]

2. Hemeida, F.A.E.A.O. Green Nanoarchitecture. Master's Thesis, University of Alexandria, Alexandria, Egypt, 2010.

3. Bidini, G.; Barelli, L.; Buratti, C.; Speranzini, E.; Castori, G.; Belloni, E. A Multidisciplinary Approach to the Study of Structural Glass Panels: Preliminary Results. In AIP Conference Proceedings, Proceedings of the 74th Conference of the Italian Thermal Machines Engineering Association (ATI 2019), Modena, Italy, 11-13 September 2019; Cantore, G., Rinaldini, C.A., Allesina, G., Pedrazzi, S., Eds.; AIP Publishing: Melville, NY, USA, 2019; p. 020021. [CrossRef]

4. Kosny, J.; Fontanini, A.D.; Shukla, N.; Fallahi, A.; Watts, A.; Trifu, R.; Ganapathysubramanian, B. Thermal performance analysis of residential attics containing high performance aerogel-based radiant barriers. Energy Build. 2018, 158, 1036-1048. [CrossRef]

5. Mohamed, R.; Mustaffa, S.A.S.; Norizan, M.N.; Mohamed, R.R.R. Thermal Degradation and Flammability of Aerogel Incorporated UPR/EPS Composites with Organic Nanocrystal Presence. In AIP Conference Proceedings, Proceedings of the 2017 National Symposium on Polymeric Materials (NSPM 2017); Romli, A.Z., Dahan, R.M., Ibrahim, N.N.I.N., Saad, S.Z., Kamarun, D., Mohamed, R., Eds.; AIP Publishing: Melville, NY, USA, 2018. [CrossRef]

6. Ibrahim, M.; Biwole, P.H.; Achard, P.; Wurtz, E. Aerogel-based materials for improving the building envelope's thermal behavior: A brief review with a focus on a new aerogel-based rendering. In Green Energy and Technology: Energy Sustainability Through Green Energy; Sharma, A., Kar, S., Eds.; Springer: New Delhi, India, 2015; pp. 163-188. [CrossRef]

7. Huang, L. Feasibility Study of using Silica Aerogel as Insulation for Buildings. Master's Thesis, KTH School of Industrial Engineering and Management, Stockholm, Sweden, 2012.

8. Buratti, C.; Belloni, E.; Merli, F.; Moretti, E. Acoustic performance of translucent aerogel-based materials. In Translucent Silica Aerogel: Properties, Preparation and Applications; Buratti, C., Ed.; Nova Science Publisher: Hauppauge, NY, USA, 2019.

9. Gao, T.; Ihara, T.; Grynning, S.; Jelle, B.P.; Lien, A.G. Perspective of aerogel glazings in energy efficient buildings. Build. Environ. 2016, 95, 405-413. [CrossRef]

10. Cuce, E.; Cuce, P.M.; Wood, C.J.; Riffat, S.B. Toward aerogel based thermal superinsulation in buildings: A comprehensive review. Renew. Sustain. Energy Rev. 2014, 34, 273-299. [CrossRef]

11. Riffat, S.B.; Qiu, G. A review of state-of-the-art aerogel applications in buildings. Int. J. Low Carbon Technol. 2013, 8, 1-6. [CrossRef]

12. Buratti, C.; Merli, F.; Moretti, E. Aerogel-based materials for building applications: Influence of granule size on thermal and acoustic performance. Energy Build. 2017, 152, 472-482. [CrossRef]

13. Moretti, E.; Merli, F.; Cuce, E.; Buratti, C. Thermal and acoustic properties of aerogels: Preliminary investigation of the influence of granule size. Energy Procedia 2017, 111, 472-480. [CrossRef]

14. Moretti, E.; Zinzi, M.; Merli, F.; Buratti, C. Optical, thermal, and energy performance of advanced polycarbonate systems with granular aerogel. Energy Build. 2018, 166, 407-417. [CrossRef]

15. Sadineni, S.B.; Madala, S.; Boehm, R.F. Passive building energy savings: A review of building envelope components. Renew. Sustain. Energy Rev. 2011, 15, 3617-3631. [CrossRef]

16. Fricke, J. Aerogels-Highly tenuous solids with fascinating properties. J. Non Cryst. Solids 1988, 100, 169-173. [CrossRef]

17. Fricke, J.; Emmerling, A. Aerogels. J. Am. Ceram. Soc. 1992, 75, 2027-2035. [CrossRef]

18. Carraher, C.E., Jr. Silica aerogels-Properties and uses. Polym. News 2005, 30, 386-388. [CrossRef]

19. Schultz, J.M.; Jensen, K.I.; Kristiansen, F.H. Super insulating aerogel glazing. Sol. Energy Mater. Sol. Cells 2005, 89, 275-285. [CrossRef]

20. Dorcheh, A.S.; Abbasi, M.H. Silica aerogel; synthesis, properties and characterization. J. Mater. Process. Technol. 2008, 199, 10-26. [CrossRef]

21. Dowson, M.; Pegg, I.; Harrison, D.; Dehouche, Z. Predicted and in situ performance of a solar air collector incorporating a translucent granular aerogel cover. Energy Build. 2012, 49, 173-187. [CrossRef]

22. Akimov, Y.K. Fields of application of aerogels (review). Instrum. Exp. Tech. 2003, 46, 287-299. [CrossRef]

23. Lassandro, P.; Cosola, T. Climate change mitigation: Resilience indicators for roof solutions. Int. J. Disaster Resil. Built Environ. 2018, 9, 4-17. [CrossRef]

24. Berardi, U. The development of a monolithic aerogel glazed window for an energy retrofitting project. Appl. Energy 2015, 154, 603-615. [CrossRef] 
25. Zheng, D.; Chen, Y.; Liu, Y.; Li, Y.; Zheng, S.; Lu, B. Experimental comparisons on optical and thermal performance between aerogel glazed skylight and double glazed skylight under real climate condition. Energy Build. 2020, 222, 110028. [CrossRef]

26. Kosny, J.; Petrie, T.; Yarbrough, D.; Childs, P.; Syed, A.M.; Blair, C. Nano-Scale Insulation at Work: Thermal Performance of Thermally Bridged Wood and Steel Structures Insulated with Local Aerogel Insulation. In Thermal Performance of the Exterior Envelopes of Whole Buildings 2007, Proceedings of the 10th International Conference on Thermal Performance of the Exterior Envelopes of Whole Buildings 2007, FL, USA, 1 January 2007; American Society of Heating, Refrigeration, and Air-Conditioning Engineers (ASHRAE): Atlanta, GA, USA, 2007.

27. Morelli, M.; Rønby, L.; Mikkelsen, S.E.; Minzari, M.G.; Kildemoes, T.; Tommerup, H.M. Energy retrofitting of a typical old Danish multi-family building to a "nearly-zero" energy building based on experiences from a test apartment. Energy Build. 2012, 54, 395-406. [CrossRef]

28. Puad, N.H.A.; Nuruddin, M.F.; Lian, J.J.; Othman, I. Roof Insulation Material from Low Density Polyethylene (LDPE), Kapok Fibre and Silica Aerogel. In Engineering Challenges for Sustainable Future, Proceedings of the 3rd International Conference on Civil, Offshore and Environmental Engineering (ICCOEE 2016), Kuala Lumpur, Malaysia, 15-17 August 2016; Zawawi, N.A.W.A., Ed.; CRC Press: Boca Raton, FL, USA; pp. 537-542. [CrossRef]

29. Biseniece, E.; Žogla, G.; Kamenders, A.; Purviňš, R.; Kašs, K.; Vanaga, R.; Blumberga, A. Thermal performance of internally insulated historic brick building in cold climate: A long term case study. Energy Build. 2017, 152, 577-586. [CrossRef]

30. Hu, J.; Chen, W.; Ren, S.; Zhang, S.; Qu, Y.; Yin, Y.; Yang, D. Building performance monitoring and analysis of a large-span aerogel-membrane airport terminal. Eng. Struct. 2020, 219, 110837. [CrossRef]

31. Cotana, F.; Pisello, A.L.; Moretti, E.; Buratti, C. Multipurpose characterization of glazing systems with silica aerogel: In-field experimental analysis of thermal-energy, lighting and acoustic performance. Build. Environ. 2014, 81, 92-102. [CrossRef]

32. Mujeebu, M.A.; Ashraf, N.; Alsuwayigh, A.H. Effect of nano vacuum insulation panel and nanogel glazing on the energy performance of office building. Appl. Energy 2016, 173, 141-151. [CrossRef]

33. Mujeebu, M.A.; Ashraf, N.; Alsuwayigh, A.H. Energy performance and economic viability of nano aerogel glazing and nano vacuum insulation panel in multi-story office building. Energy 2016, 113, 949-956. [CrossRef]

34. Buratti, C.; Moretti, E.; Belloni, E.; Merli, F.; Piermatti, V.; Ihara, T. Field Experimental Study on Energy Performance of Aerogel Glazings with Hollow Silica: Preliminary Results in Mid-Season Conditions. In Smart Innovation, Systems and Technologies, Proceedings of the 11th International Conference on Sustainability and Energy in Buildings (SEB 2019), Budapest, Hungary, 4-5 July 2019; Littlewood, J., Howlett, R.J., Howlett, R.J., Jain, L.C., Capozzoli, A., Jain, L.C., Eds.; Springer: Singapore, 2019; Volume 163, pp. 185-197. [CrossRef]

35. Zheng, D.; Chen, Y.; Lu, B. Field Surveys on the Daylighting and Thermal Environment of an Atrium with Aerogel Glazed Roof in Hot Summer and Cold Winter Zone. In Creative and Smart Solutions for Better Built Environments; International Society of Indoor Air Quality and Climate: Seoul, Korea, 2020; p. 166587.

36. Abdul Mujeebu, M.; Ashraf, N. Impact of location and deadband on energy performance of nano aerogel glazing for office building in Saudi Arabia. Build. Res. Inf. 2020, 48, 645-658. [CrossRef]

37. Al-Obaidi, K.M.; Ismail, M.; Abdul Rahman, A.M. Investigation of passive design techniques for pitched roof systems in the tropical region. Mod. Appl. Sci. 2014, 8, 182-191. [CrossRef]

38. Farhan, S.A.; Ismail, F.I.; Kiwan, O.; Shafiq, N.; Zain-Ahmed, A.; Husna, N.; Hamid, A.I.A. Effect of roof tile colour on heat conduction transfer, roof-top surface temperature and cooling load in modern residential buildings under the tropical climate of Malaysia. Sustainability 2021, 13, 4665. [CrossRef]

39. BSI. BS EN 197-1: Cement. Composition, Specifications and Conformity Criteria for Common Cements; The British Standards Institution: London, UK, 2011. [CrossRef]

40. BSI. BS EN 1008: Mixing Water for Concrete. Specification for Sampling, Testing and Assessing the Suitability of Water, including Water Recovered from Processes in the Concrete Industry, as Mixing Water for Concrete; The British Standards Institution: London, UK, 2002. [CrossRef]

41. Hamdan, H. Silica Aerogels. U.S. Patent 7,897,648 B2, 1 March 2011.

42. ASTM. ASTM C305-20: Standard Practice for Mechanical Mixing of Hydraulic Cement Pastes and Mortars of Plastic Consistency; ASTM International: West Conshohocken, PA, USA, 2020. [CrossRef]

43. BSI. BS EN 12390-2: Testing hardened Concrete. Making and Curing Specimens for Strength Tests; The British Standards Institution: London, UK, 2019. [CrossRef]

44. Kim, G.S.; Hyun, S.H. Effect of mixing on thermal and mechanical properties of aerogel-PVB composites. J. Mater. Sci. 2003, 38, 1961-1966. [CrossRef]

45. ASTM. ASTM D638-14: Standard Test Method for Tensile Properties of Plastics; ASTM International: West Conshohocken, PA, USA, 2014. [CrossRef]

46. ASTM. ASTM D790-17: Standard Test Methods for Flexural Properties of Unreinforced and Reinforced Plastics and Electrical Insulating Materials; ASTM International: West Conshohocken, PA, USA, 2017. [CrossRef]

47. ASTM. ASTM D7984-16: Standard Test Method for Measurement of Thermal Effusivity of Fabrics Using a Modified Transient Plane Source (MTPS) Instrument; ASTM International: West Conshohocken, PA, USA, 2016. [CrossRef]

48. UBBL 1984. Uniform Building By-Laws 1984. G.N. 5178/85; International Law Book Services: Petaling Jaya, Selangor, Malaysia, 2013. 
49. Irwan, S.S.; Ahmed, A.Z.; Ibrahim, N.; Zakaria, N.Z. Roof angle for optimum thermal and energy performance of insulated roof. In Proceedings of the 3rd International Conference on Energy and Environment (ICEE2009), Malacca, Malaysia, 7-8 December 2009; pp. 145-150. [CrossRef]

50. Irwan, S.S.; Ahmed, A.Z.; Zakaria, N.Z.; Ibrahim, N. Thermal and energy performance of conditioned building due to insulated sloped roof. AIP Conf. Proc. 2010, 1250, 476. [CrossRef]

51. Halim, N.H.A.; Ahmed, A.Z.; Zakaria, N.Z. Thermal and energy analysis of ceiling and pitch insulation for buildings in Malaysia. In Proceedings of the 3rd International Symposium and Exhibition in Sustainable Energy and Environment (ISESEE 2011), Malacca, Malaysia, 1-3 June 2011; pp. 214-220. [CrossRef]

52. Morris, F.; Ahmed, A.Z.; Zakaria, N.Z. Thermal performance of naturally ventilated test building with pitch and ceiling insulation. In Proceedings of the 3rd International Symposium and Exhibition in Sustainable Energy and Environment (ISESEE 2011), Malacca, Malaysia, 1-3 June 2011; pp. 221-226. [CrossRef]

53. Morris, F.; Zakaria, N.Z.; Ahmed, A.Z. Heat flux through naturally ventilated building in Malaysian climate. Appl. Mech. Mater. 2012, 204-208, 4384-4388. [CrossRef]

54. Zakaria, N.Z.; Ahmed, A.Z.; Ariffin, N.N.; Halim, N.H.A.; Morris, F. Thermal energy evaluation of building with ceiling insulation in warm-humid tropical climate. In Proceedings of the 2011 IEEE Colloquium on Humanities, Science and Engineering (CHUSER 2011), Penang, Malaysia, 5-6 December 2011; pp. 233-238. [CrossRef]

55. Munasir, S.; Triwikantoro, Z.; Darminto. Synthesis of silica nanopowder produced from Indonesian natural sand via alkalifussion route. AIP Conf. Proc. 2013, 1555, 28-31. [CrossRef]

56. Bostanc1, L.; Ustundag, O.; Sola, O.C.; Uysal, M. Effect of various curing methods and addition of silica aerogel on mortar properties. Građevinar 2019, 8, 651-661. [CrossRef]

57. Ng, S.; Sandberg, L.I.C.; Jelle, B.P. Insulating and strength properties of an aerogel-incorporated mortar based on UHPC formulations. Key Eng. Mater. 2015, 629-630, 43-48. [CrossRef]

58. Zolfaghari, S.; Paydayesh, A.; Jafari, M. Mechanical and thermal properties of polypropylene/silica aerogel composites. J. Macromol. Sci. Part B 2019, 58, 305-316. [CrossRef]

59. Thongpin, C.; Sripethdee, C.; Rodsantiea, R. Cure characteristic, mechanical properties and morphology of in-situ silicagel/NR composites. In Proceedings of the 18th International Conference on Composite Materials (ICCM18), Jeju Island, Korea, 21-26 August 2011.

60. Wucherer, L.; Nino, J.C.; Subhash, G. Mechanical properties of $\mathrm{BaTiO}_{3}$ open-porosity foams. J. Eur. Ceram. Soc. 2009, 29, 1987-1993. [CrossRef]

61. Chen, C.; Justice, R.S.; Schaefer, D.W.; Baur, J.W. Highly dispersed nanosilica-epoxy resins with enhanced mechanical properties. Polymer 2008, 49, 3805-3815. [CrossRef]

62. Mazlan, N.; Termazi, N.; Rashid, S.A.; Rahmanian, S. Investigations on composite flexural behaviour with inclusion of CNT enhanced silica aerogel in epoxy nanocomposites. Appl. Mech. Mater. 2015, 695, 179-182. [CrossRef]

63. Shahroze, R.M.; Ishak, M.R.; Sapuan, S.M.; Leman, Z.; Chandrasekar, M.; Asim, M. Effect of silica aerogel additive on mechanical properties of the sugar palm fiber-reinforced polyester composites. Int. J. Polym. Sci. 2019, 2019, 3978047. [CrossRef] 